\title{
Synthesis and Reactivity Studies of Cationic Ir(III) Alkylidines. $\alpha$-Hydride Abstraction Reactions
}

\author{
Jesús Campos and Ernesto Carmona* \\ Instituto de Investigaciones Químicas (IIQ), Departamento de Química Inorgánica and Centro de Innovación en Química \\ Avanzada (ORFEO-CINQA). Universidad de Sevilla and Consejo Superior de Investigaciones Científicas (CSIC). \\ Avenida Américo Vespucio 49, 41092 Sevilla (Spain). \\ Fax: (+34) 954460565 \\ E-mail: guzman@us.es
}

Received October 18th, 2016; Accepted February 10th, 2017.

In memory of Professor Roberto Sánchez Delgado, dear friend and outstanding leader and scientist.

\begin{abstract}
The chemistry of late transition metal alkylidenes $\left[\mathrm{M}=\mathrm{CR}_{2}\right]$, where $\mathrm{R}$ is $\mathrm{H}$ a hydrocarbyl group, have attracted widespread attention although mainly with reference to complexes of metals in low oxidation state. We focus in this paper on reactions based on electrophilic attacks by $\mathrm{Ph}_{3} \mathrm{C}^{+}$that allow either isolation of stable cationic $\operatorname{Ir}(\mathrm{III})$ alkylidenes, considerably more attractive than well-known $\operatorname{Ir}(\mathrm{I})$ counterparts, or the generation of very reactive variants that experience fast migratory insertion into existing $\mathrm{Ir}-\mathrm{C}$ and $\mathrm{Ir}-\mathrm{H}$ sigma bonds. The present studies are based on $\left(\eta^{5}-\mathrm{C}_{5} \mathrm{Me}_{5}\right) \operatorname{Ir}(\mathrm{III})$ complexes that bear a cyclometalated $\mathrm{PMeXyl}_{2}$ ligand $\left(\mathrm{Xyl}=2,6-\mathrm{Me}_{2} \mathrm{C}_{6} \mathrm{H}_{3}\right)$. The contribution of different monoanionic ligands (chloride, alkyl or hydride) to either stabilize the $\mathrm{Ir}=\mathrm{CR}_{2}$ linkage or provide facile reactivity routes has been investigated, including the use of various deuterium isotopologues of the iridium complex precursors.
\end{abstract}

Keywords. Alkylidene; Hydride abstraction; Iridium; C-C coupling; Metalacycle.

\section{Introduction}

Carbenes have been widely utilized as spectator ligands since the development of N-heterocylicarbenes (NHCs) [1] and more recently of the related cyclic (alkyl)(amino)carbenes (CAACs),[2] owing to their synthetic availability, the facility of modulating their steric and electronic properties and not least the kinetic and thermodynamic stability they confer to transition metal complexes. Together with cyclopentadienyls, tertiary phosphines and related P-donors, carbenes have become ubiquitous in transition metal chemistry including applications in homogeneous catalysis.[1] Besides, the rich reactivity of the $\mathrm{M}=\mathrm{C}$ bond places metal carbenes in a prominent position in organometallic chemistry.

Carbocyclic[3] and heteroatom-stabilized carbenes (CRX; $\mathrm{X}=\mathrm{OR}$ ', NR' ${ }_{2}$ and other groups)[4],[5] have been amply investigated and their reactivity comprehensively analyzed.[6],[7] A highly attractive and important group of carbenes are the socalled alkylidenes, examples of which are discussed in this article. With an ever growing number of carbene complexes of
Resumen. La química de los complejos de los metales de transición de los últimos grupos con ligantes alquilideno, $\left[\mathrm{M}=\mathrm{CR}_{2}\right]$, donde $\mathrm{R}$ es $\mathrm{H}$ o un grupo hidrocarbilo, es un área de gran interés, aunque con referencia principalmente a estados de oxidación bajos. En este trabajo se describen reacciones de ataque electrofílico mediante $\mathrm{Ph}_{3} \mathrm{C}^{+}$que permiten el aislamiento de alquilidenos catiónicos de $\operatorname{Ir}(\mathrm{III})$, de mayor interés que los bien conocidos análogos de $\operatorname{Ir}(\mathrm{I})$, o alternativamente, la generación de especies muy reactivas que experimentan con rapidez reacciones de inserción migratoria en enlaces sigma Ir-C o Ir-H preexistentes. Los estudios que se describen se basan en complejos de la agrupación $\left(\eta^{5}-\mathrm{C}_{5} \mathrm{Me}_{5}\right)$ $\mathrm{Ir}(\mathrm{III})$ con el ligante $\mathrm{PMeXyl}_{2}$ ciclometalado $\left(\mathrm{Xil}=2,6-\mathrm{Me}_{2} \mathrm{C}_{6} \mathrm{H}_{3}\right.$ ). Se ha investigado la capacidad de diferentes ligantes monoaniónicos (cloruro, alquilo o hidruro) para estabilizar el enlace $\mathrm{Ir}=\mathrm{CR}_{2}$, o para proporcionar otras rutas de reacción fáciles para lo cual se han utilizado diversos isotópologos deuterados de los complejos precursores de iridio.

Palabras clave: Alquilideno; abstracción de hidruro; iridio; acoplamiento C-C; metalaciclo.

diverse reactivity, some confusion about their nomenclature has arisen. It is, therefore, pertinent to clarify that in accordance with IUPAC nomenclature, alkylidene complexes contain a $\mathrm{M}=\mathrm{CRR}$ ' bond where $\mathrm{R}, \mathrm{R}$ ' are hydrogen, alkyl, aryl and the like.[8] At variance with Fischer carbenes, that hold one or two heteroatoms bonded to the carbene atom, metal alkylidenes cannot be classified in a general manner as electrophilic or nucleophilic, for $\mathrm{M}=\mathrm{CRR}$ ' termini of the two types exist depending on the metal, the carbene ligand and the other ligands of the complex. The capacity of metal alkylidenes to exhibit Fischer- (electrophilic) or Schrock-type (nucleophilic) reactivity has been widely exploited in homogeneous catalysis, most notably in an ample variety of olefin metathesis reactions.[9]

Although metal alkylidenes of late transition elements including iridium are typically stabilized by low oxidation states,[10],[11] over the years, our group studied the chemistry of $\operatorname{Ir}(\mathrm{III})$ complexes of hydrotris(pyrazolyl)borate ligands with carbenes of both the :CRR' and :CRX types.[4a,b] The Ir-carbene unit was in many cases generated by double $\mathrm{C}-\mathrm{H}$ bond activation reactions and we further authenticated unusual 
alkene-to-alkylidene reversible rearrangements involving reversible $\alpha$ - and $\beta$-hydrogen elimination reactions.[12] $\operatorname{Ir}($ III) alkylidenes, particularly cationic variants, are highly electrophilic[13] and have been proposed as reactive intermediates for several relevant transformations,[14] including the cleavage of carbon-fluorine[15] and carbon-carbon[16] bonds.

Pursuing these studies further and following the pioneer work of Bergman and coworkers in the use of $\left[\left(\eta^{5}-\mathrm{C}_{5} \mathrm{Me}_{5}\right)\right.$ $\left.\operatorname{Ir}(\mathrm{Me})\left(\mathrm{PMe}_{3}\right)(\mathrm{S})\right]^{+}$for the selective activation of $\mathrm{C}-\mathrm{H}$ bonds [17] $\left(\mathrm{S}=\right.$ solvent), we recently showed that $\left(\eta^{5}-\mathrm{C}_{5} \mathrm{Me}_{5}\right) \operatorname{Ir}(\mathrm{III}) \mathrm{com}-$ plexes of dialkylxylyl phosphines, $\mathrm{PR}_{2}(\mathrm{Xyl})\left(\mathrm{R}={ }^{i} \mathrm{Pr}\right.$, Cy; Xyl $\left.=2,6-\mathrm{Me}_{2} \mathrm{C}_{6} \mathrm{H}_{3}\right),[18]$ allowed isolation of stable cationic $\operatorname{Ir}(\mathrm{III})$ alkylidenes (structure A in Fig. 1) in reactions that required the activation of two benzylic C-H bonds.[19] Under similar conditions the related $\mathrm{PMeXyl}_{2}$ ligand afforded the cyclometalated structure B (Fig. 1) with uncommon $\eta^{4}$-P-pseudoallyl coordination of the metalated ligand.[20] Further reactivity resulted in bicylic complex $\mathbf{C}$ from which $\alpha$-hydride abstraction by $\mathrm{Ph}_{3} \mathrm{C}^{+}$ led first to the alkyl-alkylidene $\mathbf{D}$ and ultimately to an intriguing hydride phosphepine complex (not shown in Fig. 1) by migratory insertion of the alkylidene into the iridium alkyl bond. [20] Related $\mathrm{Ph}_{3} \mathrm{C}^{+}$promoted $\mathrm{C}-\mathrm{C}$ bond forming reactions have been disclosed recently by our group.[21]

Such electrophilic attacks to carbon-based ligands are important reactions that occur often without cleavage of the metal-carbon bond.[22],[23] Specifically, action of $\mathrm{Ph}_{3} \mathrm{C}^{+}$on a metal-alkyl bond is known to yield a metal-carbene in a process thought to occur with initial electron transfer from the metal to $\mathrm{Ph}_{3} \mathrm{C}^{+}$, followed by $\alpha-\mathrm{H}$ atom transfer.[24] We thought of interest to broaden further recent related reactivity studies on platinum[25] and iridium $10^{\mathrm{e}}$ complexes, and in this paper we have extended these investigations, concentrating attention on the four $\left(\eta^{5}-\mathrm{C}_{5} \mathrm{Me}_{5}\right) \mathrm{Ir}(\mathrm{III})$ complexes shown in Fig. 2. As discussed later, some stable cationic Ir(III) alkylidenes have been isolated, along with somewhat related hydride alkene complexes. In addition, other $\mathrm{C}-\mathrm{C}$ bond coupling reactions implicating transient carbenes derived from diazo compounds[26] have been investigated.

\section{Results and Discussion}

\section{$\mathrm{Ph}_{3} \mathrm{C}^{+}$promoted hydride abstraction reactions}

The four Ir(III) complexes selected for this work (Fig. 2) contain a five-member phosphine-alkyl metalacycle that results from metalation of a $\delta$ benzylic bond of a $\mathrm{PMeXyl}_{2}$ ligand.[18] Chloride 1-Cl was the parent complex within this family, whereas 1-H and 1-Me are the corresponding hydride and methyl derivatives. Compound 2, that resulted from the reaction of 1-Cl with $\mathrm{LiBu}^{n},[18 \mathrm{a}]$ is an unusual bis(iridacycle) that besides the common five member iridacycle holds an unusual three member $\mathrm{Ir}_{-} \mathrm{CH}_{2}-\mathrm{P}$ moiety that stems from the metalation of the P-Me bond. Clearly, as the four possess an $\mathrm{Ir}-\mathrm{CH}_{2}$ bond within the five member ring they are prone to undergo $\alpha-\mathrm{H}$ abstraction. But in addition, 1-Me and $\mathbf{2}$ bear another iridium-al$\mathrm{kyl}$ bond that could compete with the $\mathrm{Ir}-\mathrm{CH}_{2}$ metalacyclic bond for electrophilic attack by $\mathrm{Ph}_{3} \mathrm{C}^{+}$. Moreover, complex 1-H may also experience $\alpha$-hydride abstraction at the Ir-H bond, which is a common reaction of metal hydrides[22],[23] that appears to imply a single-step hydride transfer.[27]
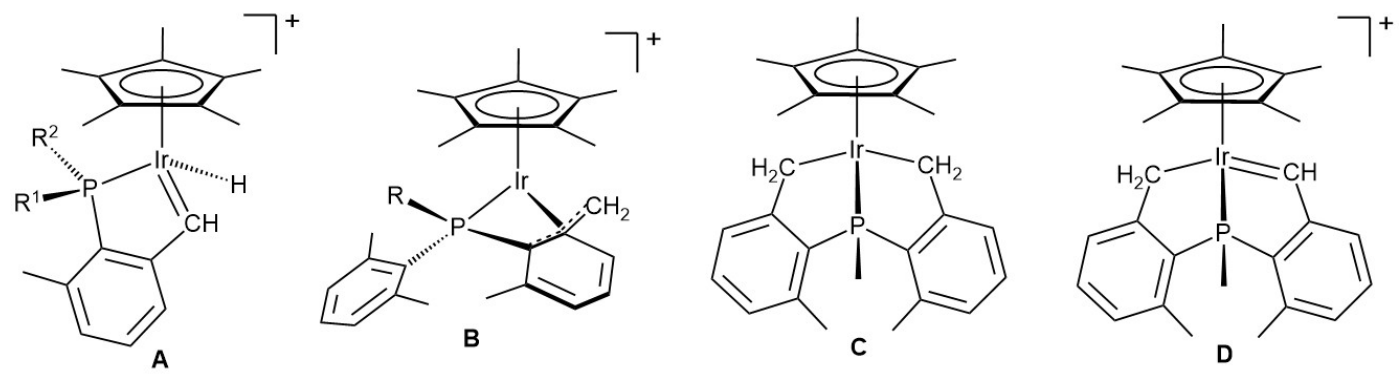

Fig. 1. Previous examples from our group of $\left(\eta^{5}-\mathrm{C}_{5} \mathrm{Me}_{5}\right) \operatorname{Ir}(\mathrm{III})$ structures containing cyclometalated xylylphosphine ligands.<smiles>[Y4][PH]1(C)c2c(C)cccc2C[Al]1Cl</smiles>

$1-\mathrm{Cl}$
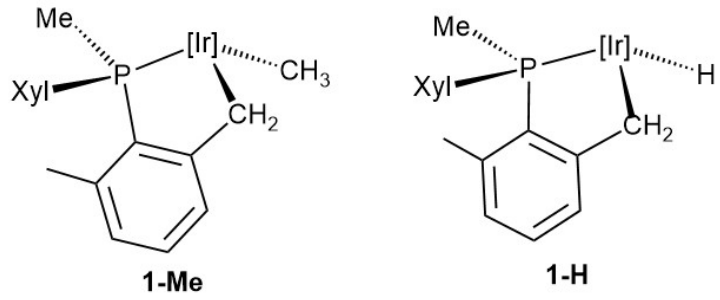

1-H

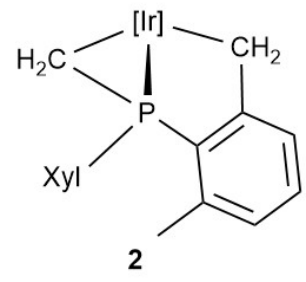

Fig. 2. $\operatorname{Ir}(\mathrm{III})$ metalacycles studied in this work $\left([\mathrm{Ir}]=\left(\eta^{5}-\mathrm{C}_{5} \mathrm{Me}_{5}\right) \operatorname{Ir}\right)$ 
Scheme 1 summarizes the outcome of the low-temperature reactions of complexes 1-Cl (A), 2 (B) and 1-H (C), with trityl salts, $\left[\mathrm{Ph}_{3} \mathrm{C}\right]^{+}[\mathrm{X}]^{-}\left(\mathrm{X}=\mathrm{PF}_{6}\right.$ or $\left.\mathrm{B}\left(\mathrm{C}_{6} \mathrm{~F}_{5}\right)_{4}\right)$. In all cases a single reaction product was obtained though, as discussed later, formation of complex $\mathbf{1}^{+}$from $\mathbf{1 - H}$ is more complex than may be inferred from Scheme 1C. At variance with these observations, the analogous reaction of 1-Me (Scheme 2) gives a mixture of products and will be analyzed separately.

Compounds 1-Cl and $\mathbf{2}$ underwent formal $\alpha$-hydride abstraction at the $\mathrm{Ir}-\mathrm{CH}_{2}$ bond of their five member metalacycle forming the cationic alkylidene complexes $\mathbf{3}$ and $\mathbf{4}$, respectively. No reaction of the P-bonded methylene group of $\mathbf{2}$ was detected at $-80{ }^{\circ} \mathrm{C}$ or at room temperature despite literature precedent for such reactivity.[28] Regarding the formation of the pseudo-allylic complex $\mathbf{1}^{+}$as in Scheme $1 \mathrm{C}$, it is consistent with either direct Ir-H transfer to $\mathrm{Ph}_{3} \mathrm{C}^{+}$, or formation of an unobserved hydride alkylidene related to complex $\mathbf{3}$, followed by hydride attack to the highly electrophilic alkylidene carbon atom.[20b] Migratory insertion reactivity could also be expected for the cationic alkyl alkylidene complex 4. Indeed the somewhat related alkyl alkylidene D of Fig. 1 was found to undergo facile C-C bond coupling with formation of an unusual hydride phosphepine complex.[20b,c] It appears that the analogous $\mathrm{C}-\mathrm{C}$ coupling in $\mathbf{4}$ is thwarted by the rigidity of its three-membered alkyl unit that would require an energetically prohibited transition state.

Solutions of compounds 3 and $\mathbf{4}$ exhibit characteristic intense green and red colors, respectively, reminiscent of our previously synthesized $\operatorname{Ir}(\mathrm{III})$ alkylidene species $\mathbf{A}$ and $\mathbf{D}$ (Scheme 1). $[15,16 \mathrm{~b}]$ The thermal stability of compounds $\mathbf{3}$ and $\mathbf{4}$ is remarkable when considering prior examples of late transition metal electrophilic alkylidenes. Compounds $\mathbf{3}$ and $\mathbf{4}$ are stable under inert atmosphere in the solid state for long periods of time, and in dichloromethane solutions exhibit $t_{1 / 2}$ of several days at $25^{\circ} \mathrm{C}$. The two compounds are characterized (Fig. 3) by a deshielded ${ }^{1} \mathrm{H}$ NMR alkylidene signal at $16.61\left(3, \mathrm{~d},{ }^{3} J_{\mathrm{HP}}=\right.$ $0.9 \mathrm{~Hz})$ and $14.9 \mathrm{ppm}(4, \mathrm{~s})$, respectively, which are shifted by $c a .11-13 \mathrm{ppm}$ with respect to the peaks due to the diastereotopic $\mathrm{Ir}-\mathrm{CH}_{2}$ protons of $\mathbf{1 - C l}$ and 2. The corresponding ${ }^{13} \mathrm{C}\left\{{ }^{1} \mathrm{H}\right\}$ signals are found at 262.4 and $243.7\left({ }^{2} J_{\mathrm{CP}}=28 \mathrm{~Hz}\right) \mathrm{ppm}$, respectively, with the former featuring a one-bond $\mathrm{C}-\mathrm{H}$ coupling constant of $153 \mathrm{~Hz}$, in agreement with the alkylidene formulation. A marked variation in the ${ }^{31} \mathrm{P}\left\{{ }^{1} \mathrm{H}\right\}$ spectrum of $\mathbf{4}(-13.1$ $\mathrm{ppm}$ ) when compared to $\mathbf{2}(-41.6 \mathrm{ppm})$ is observed that is more significant than for the chloride compounds (from 11.3 in 1-Cl to $20.8 \mathrm{ppm}$ in $\mathbf{3}$ ). Other spectroscopic data matched those of our related and previously synthesized complexes (see Experimental Section).

Single crystals of $\mathbf{3}$ and $\mathbf{4}$ suitable for X-ray studies were obtained by slow diffusion of pentane into dichloromethane solutions of the complexes at $-20^{\circ} \mathrm{C}$. A characteristically short Ir1-C17 bond distance was measured for both compounds (1.899(5) $\AA,(3) ; 1.905(4) \AA,(4))$, that compares well to the analogous distance in compounds of type $\mathbf{A}$ in Fig. 1 (1.896(5) and 1.907(2) $\AA),[19]$ whereas the average Ir-C distance in our previously reported neutral and cationic alkyl complexes of similar structures is significantly longer $(c a .2 .12 \AA)[18 \mathrm{~b}, 20 \mathrm{~b}, \mathrm{c}]$. As shown in Fig. 4, X-ray crystallography unequivocally confirms that hydride abstraction from $\mathbf{2}$ occurred from the $\mathrm{Ir}-\mathrm{CH}_{2}$ methylene group within the five-membered ring, whereas the metalated $\mathrm{P}-\mathrm{Me}$ group remained unaltered. The $\mathrm{P} 1-\mathrm{C} 27$ bond distance $(1.750(4) \AA)$ is slightly shorter than the other two

(A)

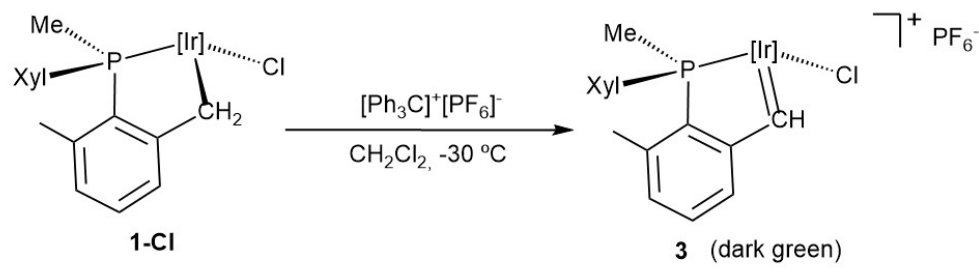

(B)

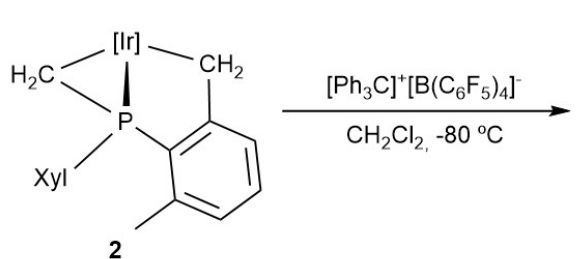

2

(C)

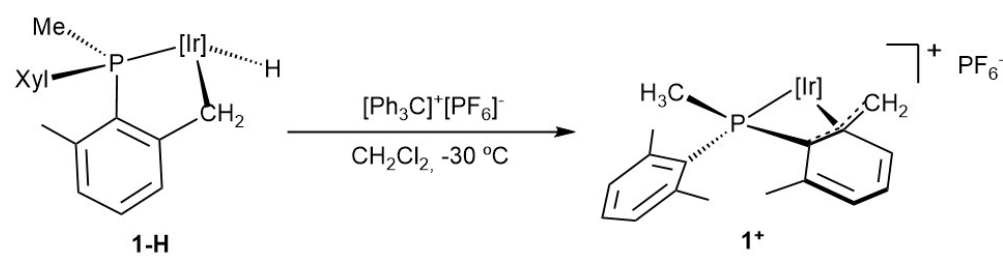

Scheme 1. $\alpha$-Hydride abstraction from neutral compounds 1-Cl, 1-H and 2. 


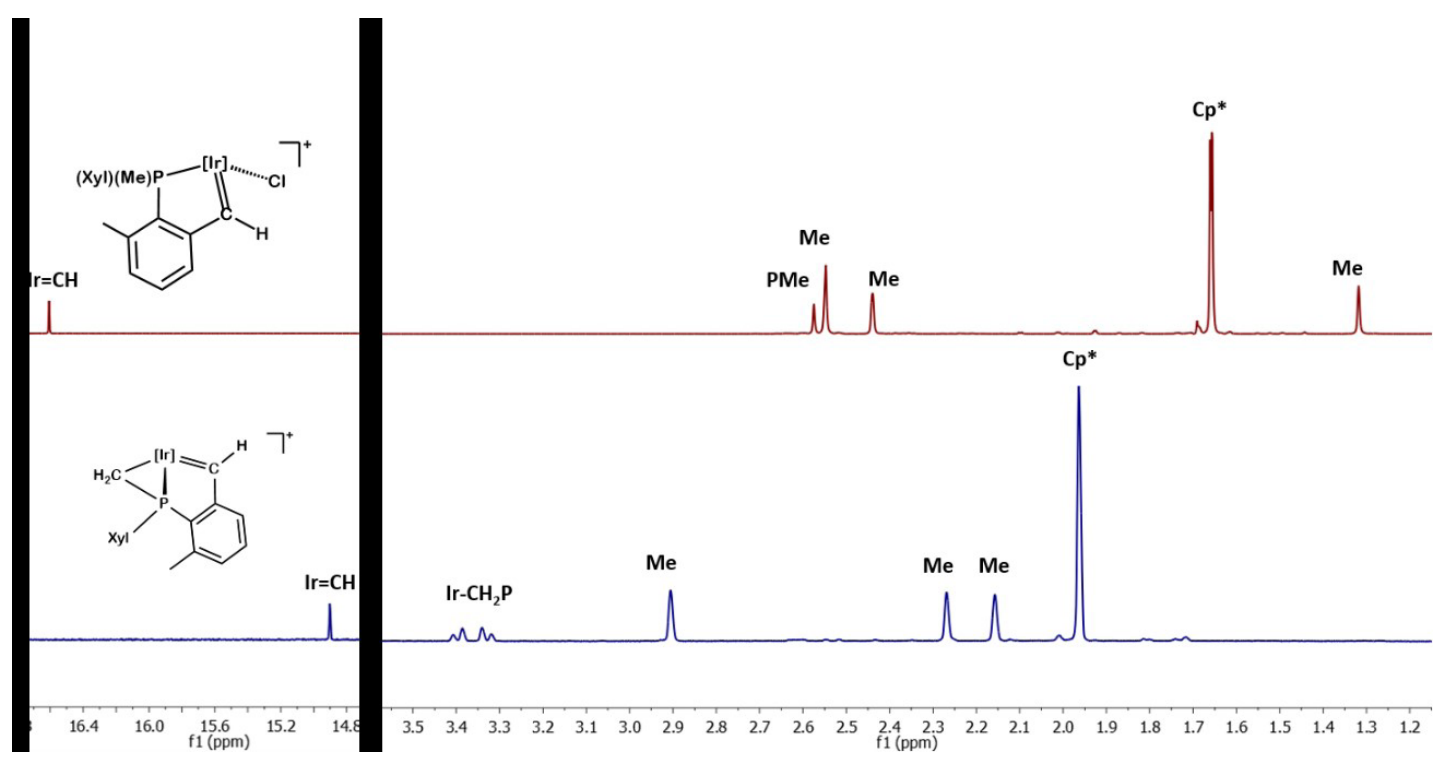

Fig. 3. ${ }^{1} \mathrm{H}$ NMR $\left(500 \mathrm{MHz}, \mathbf{C D}_{\mathbf{2}} \mathbf{C l}_{2}, 25^{\circ} \mathrm{C}\right)$ spectra of cationic alkylidenes 3 and 4 .

P1-C bonds ( $c a .1 .80 \AA$ ), most likely due to the partial double-bond character of the $\mathrm{P} 1-\mathrm{C} 27$ unit.[29] The strain within the three-membered metalacycle is clearly reflected by the acute P1-Ir1-C27 angle of $46.84^{\circ}$, less than half the value that would correspond to a tetrahedral environment around the P1 atom.

As noted briefly, the reaction of complex 1-Me with $\left[\mathrm{Ph}_{3} \mathrm{C}\right]$ $\left[\mathrm{B}\left(\mathrm{C}_{6} \mathrm{~F}_{5}\right)_{4}\right]$ yielded a variety of products (Scheme 2 ). Two of them were diastereomeric hydride alkene complexes stemming from $\mathrm{Ph}_{3} \mathrm{C}^{+}$-promoted $\mathrm{C}$ - $\mathrm{C}$ bond forming reactions (notice the existence of three stereogenic centers in the molecules of $\mathbf{5}$, which are chiral at Ir, $\mathrm{P}$ and the $\mathrm{CH}$ carbon of the coordinated olefin). The third product, rather oddly unobserved in the reactions of the other complexes investigated (Scheme 1), resulted from $\beta$-hydride abstraction from one of the $\mathrm{C}_{5} \mathrm{Me}_{5}$ methyl
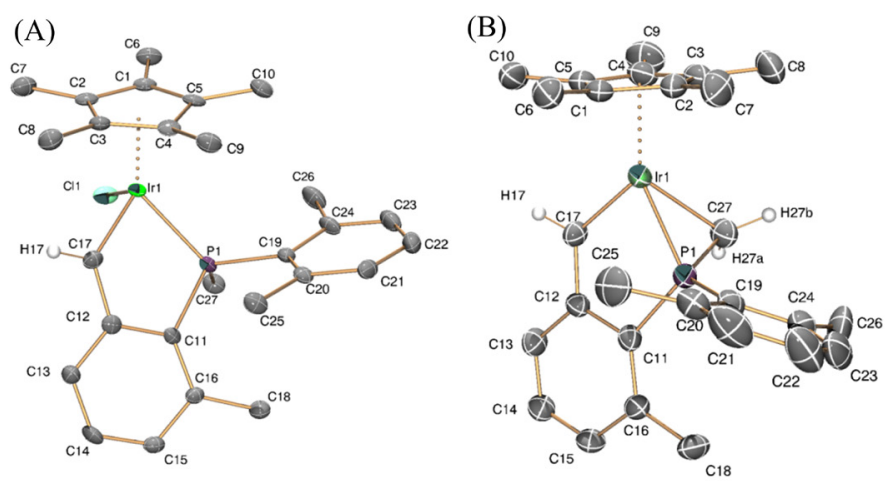

Fig. 4. ORTEP diagrams for complexes 3 (A) and 4 (B). Thermal ellipsoids are drawn at the $50 \%$ probability. Most hydrogen atoms and counterions have been omitted for clarity. groups and afforded the permethylated fulvene complex 6.[30] The reaction of Scheme 2 was started at $0^{\circ} \mathrm{C}$, and after stirring at room temperature for 30 minutes afforded a kinetic mixture of isomers $\boldsymbol{k}-\mathbf{5}, \boldsymbol{t}-\mathbf{5}$ and $\mathbf{6}$ in a $c a$. 63:7:30 proportion. Since further stirring at room temperature did not change the $\boldsymbol{k}-\mathbf{5}: t-\mathbf{5}$ ratio, it can be concluded that they form along independent, competitive reaction paths. As discussed later, complex $\boldsymbol{k}-\mathbf{5}$ derived from electrophilic attack at the $\mathrm{Ir}-\mathrm{CH}_{3}$ bond, while $\boldsymbol{t} \mathbf{- 5}$ resulted from an $\alpha-\mathrm{H}$ abstraction reaction involving the $\mathrm{Ir}-\mathrm{CH}_{2}$ unit. This kinetic mixture of diastereomers 5 converted into the thermodynamic isomer $\boldsymbol{t}-\mathbf{5}$ upon heating at $50{ }^{\circ} \mathrm{C}$ for $12 \mathrm{~h}$. ${ }^{31} \mathrm{P}\left\{{ }^{1} \mathrm{H}\right\}$ NMR monitoring at $40{ }^{\circ} \mathrm{C}$ gave a first order rate constant of $1.4 \cdot 10^{-5} \mathrm{~s}^{-1}$ (see Fig. S1), from which a $\Delta \mathrm{G}^{\neq}$value of $25.3 \pm 0.1 \mathrm{kcal} \cdot \mathrm{mol}^{-1}$ was deduced. Related isomerization reactions of Ir(III) hydride alkene complexes have been extensively studied by our group[31] and accordingly the present system was not further investigated.

Compounds $\boldsymbol{t}-\mathbf{5}$ and $\boldsymbol{k}-\mathbf{5}$ are characterized by ${ }^{1} \mathrm{H}$ NMR signals at $-15.77\left(\mathrm{~d},{ }^{2} J_{\mathrm{HP}}=30.1 \mathrm{~Hz}\right)$ and $-14.31\left(\mathrm{~d},{ }^{2} J_{\mathrm{HP}}=28.5 \mathrm{~Hz}\right)$ ppm, respectively, due to the iridium hydride group. In the ${ }^{31} \mathrm{P}\left\{{ }^{1} \mathrm{H}\right\}$ NMR spectra peaks at -0.1 and $-9.8 \mathrm{ppm}$ appear due to the thermodynamic and kinetic isomers, respectively. For the former, the olefin moiety features three ${ }^{1} \mathrm{H}$ NMR signals at 4.27 (dd), 2.83 (dt) and 2.64 (dd) ppm, due to $\mathrm{H}_{\alpha}, \mathrm{H}_{\gamma}$ and $\mathrm{H}_{\beta}$, respectively. Coupling constants are in agreement with the formulation depicted in Scheme 2, with values of 10.5 and $8.6 \mathrm{~Hz}$ for the three-bond $\mathrm{H}-\mathrm{H}$ coupling of trans $\left(\mathrm{H}_{\alpha}-\mathrm{H}_{\gamma}\right)$ and cis $\left(\mathrm{H}_{\alpha}-\mathrm{H}_{\beta}\right)$ protons, whereas the geminal ${ }^{2} J_{\mathrm{HH}}$ coupling between $\mathrm{H}_{\beta}$ and $\mathrm{H}_{\gamma}$ amounts $2.4 \mathrm{~Hz}$. No coupling to the phosphorous nucleus is observed, except for $\mathrm{H}_{\gamma}$, which exhibits a three-bond coupling of ca. $2.4 \mathrm{~Hz}$. Corresponding ${ }^{13} \mathrm{C}\left\{{ }^{1} \mathrm{H}\right\}$ NMR signals appear strongly deshielded with respect to 1-Me (which exhibits resonances at 16.9 and -22.9 ppm for $\mathrm{Ir}-\mathrm{CH}_{2}$ and $\mathrm{Ir}-\mathrm{CH}_{3}$, respectively), with values of $62.7\left(\mathrm{CH}_{\alpha}\right)$ and $34.1\left(\mathrm{CH}_{\beta} \mathrm{H}_{\gamma}\right) \mathrm{ppm}$, as expected for olefinic $\mathrm{C}^{13}$ nuclei. ${ }^{1} \mathrm{H}$ and ${ }^{13} \mathrm{C}\left\{{ }^{1} \mathrm{H}\right\}$ NMR signals 

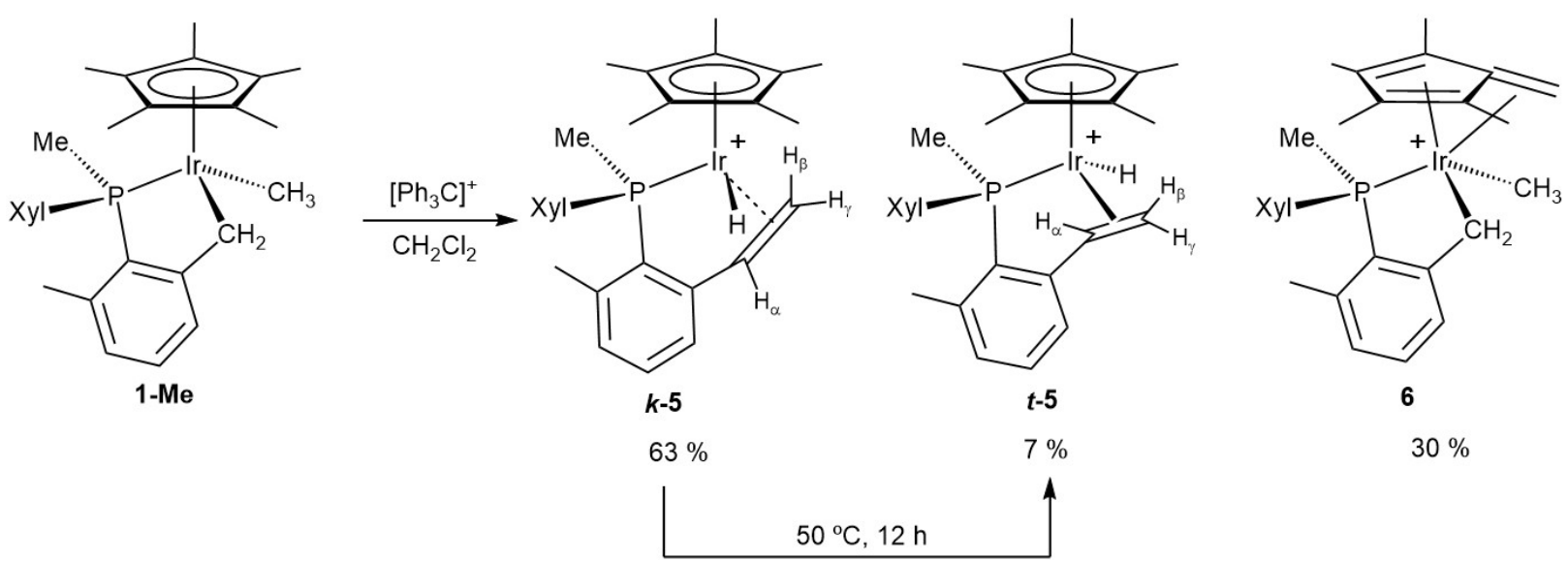

$30 \%$

Scheme 2. Reaction of 1-Me with $\left[\mathrm{Ph}_{3} \mathrm{C}\right]^{+}$and isomerization of 5 .

due to the kinetic isomer are similar to those of the thermodynamic one. The formulation depicted in Scheme 2 for the two diastereomers was tentatively inferred from 2D-NOE experiments. Compound $\boldsymbol{t} \mathbf{- 5}$ exhibits an intense NOE cross-peak between $\mathrm{Ir}-\mathrm{H}$ and $\mathrm{P}-\mathrm{Me}$, thus suggesting that both groups lie in a syn conformation. However, this cross-peak is absent in $\boldsymbol{k - 5}$, which might suggest an anti arrangement of both functionalities. As represented in Fig. 5, the structures suggested for isomers 5 were further confirmed by X-ray crystallography. These studies evidenced not only the formation of the new C-C double bond (1.470(13) and 1.473(10) $\AA$ for $\boldsymbol{k}-\mathbf{5}$ and $\boldsymbol{t} \mathbf{5}$, respectively), but also the syn (k-5) vsanti $(\boldsymbol{t}-\mathbf{5})$ orientation of the Ir-H and $\mathrm{P}-\mathrm{Me}$ units, without any other discernible structural differences. Other geometrical parameters are in agreement with previously discussed molecular structures of related compounds. [18-20]

Attempts to isolate pure complex $\mathbf{6}$ were unsuccessful. The proposedformulation is therefore tentative although finds strong support on NMR data recorded for its mixtures with isomer $\boldsymbol{t}$-5. Fig. 6 shows the ${ }^{1} \mathrm{H}$ NMR spectrum in the region $c a .3$
$-0.5 \mathrm{ppm}$ for a $c a$. $6: 4$ mixture of complexes $\boldsymbol{t}-\mathbf{5}$ and $\mathbf{6}$ that resulted fromseveral attempts of fractional crystallization. The appearance of some distinctive signals due to the presence of a 1,2,3,4-tetramethylfulvene moiety provides strong support to the proposed formulation. In particular, olefinic resonances at $5.30\left(\mathrm{~d},{ }^{4} J_{\mathrm{HP}}=4.2 \mathrm{~Hz}\right)$ and $4.54 \mathrm{ppm}$ attributed to the $\mathrm{CH}_{2}$ terminus, and at 1.80, 1.75, 1.57 and $0.76 \mathrm{ppm}$ due to inequivalent methyl groups, each with the expected relative intensity and moreover exhibiting four-bond coupling to the ${ }^{31} \mathrm{P}$ nucleus (1.4 - $2.8 \mathrm{~Hz}$ ), are conclusive and comparable to literature precedents.[30]

\section{Mechanistic considerations. Deuterium labeling studies}

As pointed out earlier, electrophilic attack by $\mathrm{Ph}_{3} \mathrm{C}^{+}$to either of the neutral molecules of 1-H and 1-Me could occur at two different bonds. For hydride 1-H these are the Ir-H and one of the Ir- $\mathrm{CH}_{2}$ sites, while for the methyl analog 1-Me, $\alpha-\mathrm{H}$ abstraction
(A)

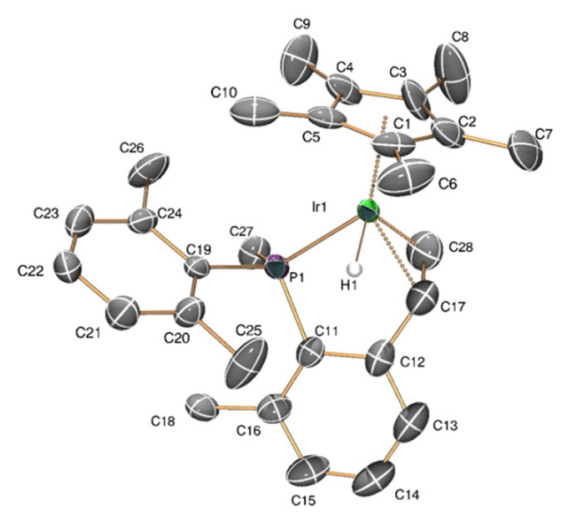

(B)

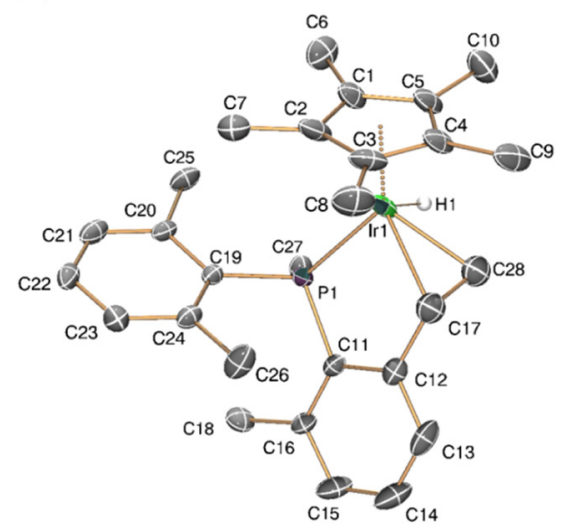

Fig. 5. ORTEP diagrams for complexes for the two diastereomers of compound 5: (A) kinetic isomer $\boldsymbol{k}$-5; (B) thermodynamic isomer $\boldsymbol{t}$-5. Thermal ellipsoids are drawn at the $50 \%$ probability. Hydrogen atoms (except Ir-H) and counterions have been omitted for clarity. 


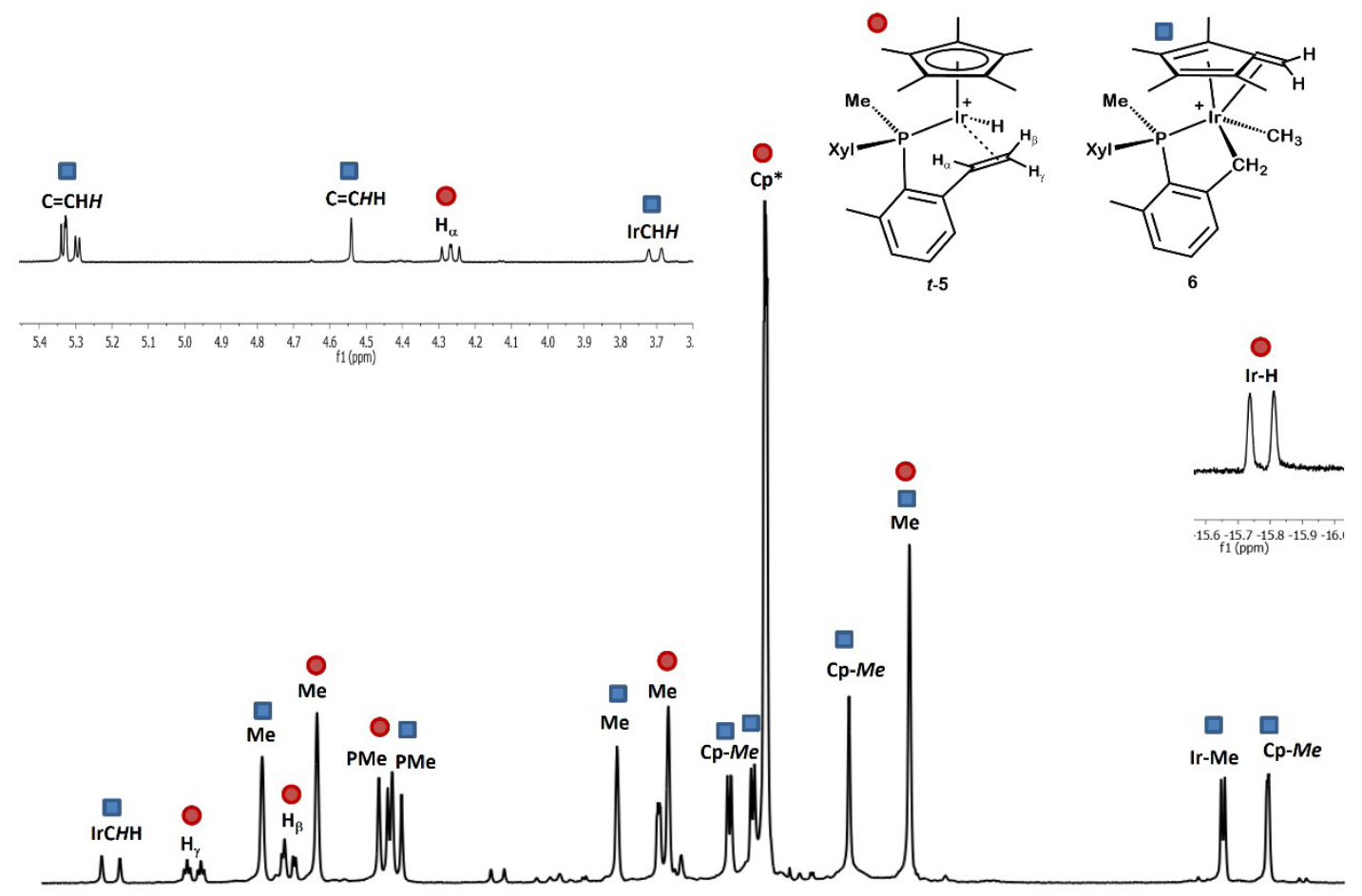

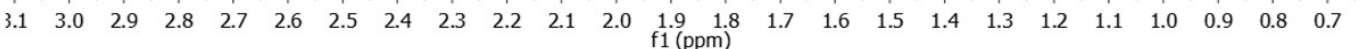

Fig. 6. ${ }^{1} \mathrm{H}$ NMR (400 MHz, $\left.\mathrm{CD}_{2} \mathrm{Cl}_{2}, 25^{\circ} \mathrm{C}\right)$ spectrum of a mixture of $\boldsymbol{t}-\mathbf{5}$ and $\mathbf{6}$ (ca. 6:4).

could occur at the Ir- $\mathrm{CH}_{3}$ and $\mathrm{Ir}-\mathrm{CH}_{2}$ locations. To gain mechanistic insights, additional experiments were undertaken using different isotopologues of the two complexes.

Hydrogen abstraction from 1-H through either the Ir-H or the $\mathrm{Ir}-\mathrm{CH}_{2}$ sites would clearly proceed through conspicuously different reaction routes, that would nonetheless turn into the same reaction outcome, namely complex $\mathbf{1}^{+}$(Scheme 1). As illustrated in Scheme 3, Ir-H abstraction would form a cationic solvento species $\mathbf{1} \mathbf{S}^{+}$, known to rearrange immediately[20] to the $\eta^{4}-P$, benzylic complex $\mathbf{1}^{+}$. Similarly, the $\mathrm{Ir}-\mathrm{CH}_{2}$ path would also produce $\mathbf{1}^{+}$albeit with initial generation of a highly electrophilic hydridoalkylidene $\mathbf{E}$, followed by a 1,2-H shift from Ir to the carbene. Isotopologues 1-D and $\left[D_{11}\right]-1-H$, selectively deuterated at the hydride and all benzylic positions of the cyclometalated phosphine, respectively, were assayed (Scheme 4). The first was prepared from 1-Cl and $\mathrm{LiAlD}_{4}[18]$ whereas the second emanated from $\mathrm{H} / \mathrm{D}$ exchange between 1-Cl and $\mathrm{CD}_{3} \mathrm{OD}[18]$ and subsequent reaction with $\mathrm{LiAlH}_{4}$. As delineated in Scheme 4, treatment of 1-D with 1 equiv of $\mathrm{Ph}_{3} \mathrm{C}^{+}$resulted in the exclusive formation of $\mathrm{Ph}_{3} \mathrm{CH}$, hinting faster Ir- $\mathrm{CH}_{2}$ over Ir-D reactivity. Nevertheless, the analogous experiment performed with isotopologue $\left[\boldsymbol{D}_{\mathbf{1 1}}\right] \mathbf{- 1 - H}$ led to $\mathrm{Ph}_{3} \mathrm{CH}(\mathrm{D})$ with ca. $50 \%$ deuterium incorporation, with protio scrambling over all benzylic positions ( $c a .5 \%)$. These results indicate that the two reactions have comparable rates, with $\mathrm{H}$-abstraction from $\mathrm{Ir}-\mathrm{CH}_{2}$ being somewhat faster than abstraction from the metal hydride site. Primary kinetic isotope effects mostly associated with the Ir- $\mathrm{CH}_{2} / \mathrm{Ir}-\mathrm{CD}_{2}$ linkages are probably responsible for the above results.

Scheme 5 shows the labeled products expected from the deuterated complexes $\left[\boldsymbol{D}_{\mathbf{1 1}}\right] \mathbf{- 1}-\mathbf{M e}$ and $\mathbf{1}-\mathbf{C D}_{\mathbf{3}}$ after hydride abstraction from either the $\mathrm{Ir}-\mathrm{CH}_{3}$ (A-top and $B$-top) or $\mathrm{Ir}-\mathrm{CH}_{2}$ (A-bottom and $B$-bottom) sites. An important aspect to keep in mind is the fact that hydride abstraction from the $\mathrm{Ir}-\mathrm{CH}_{3}$ group

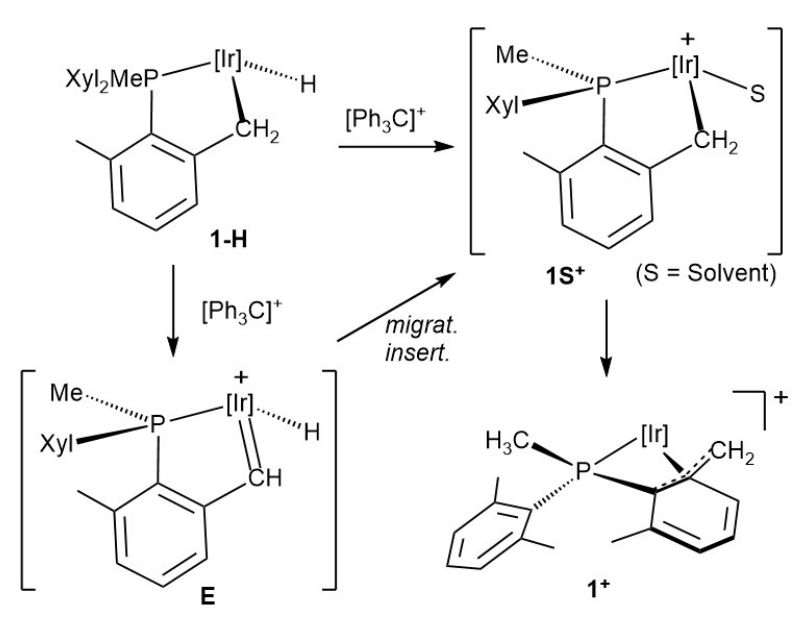

Scheme 3. Possible routes for hydride abstraction from 1-H to give $1^{+}$. 
(A)

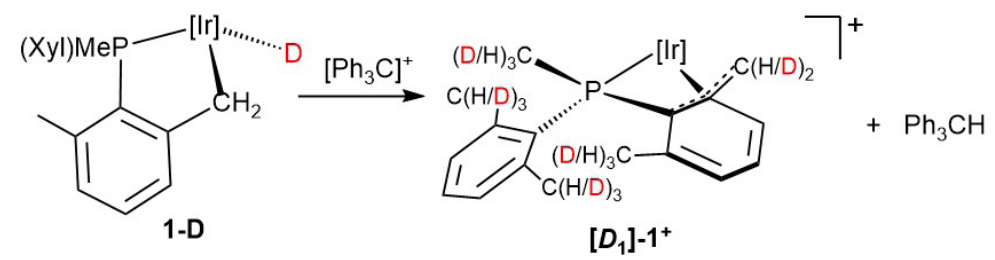

(B)

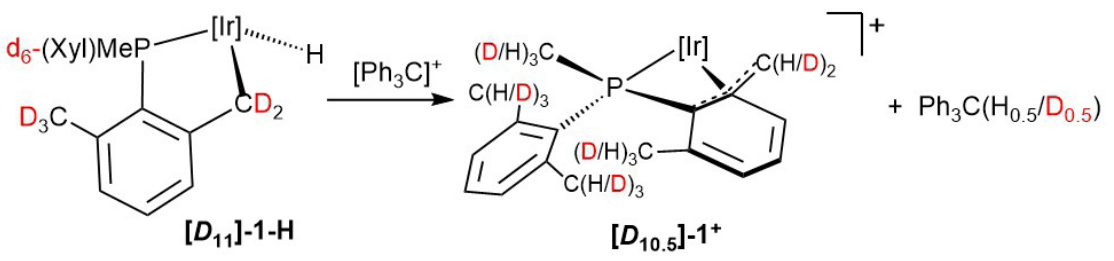

Scheme 4. Hydride abstraction by $\left[\mathrm{Ph}_{3} \mathrm{C}\right]^{+}$from 1-D and $\left[\boldsymbol{D}_{11}\right]-1-$ Hisotopologues.

would lead to a transient methylidene $\left(\mathrm{Ir}=\mathrm{CH}_{2}\right)$ that after insertion of the alkyl fragment and subsequent $\beta-\mathrm{H}$ elimination would yield the kinetic isomer of the final product $\boldsymbol{k}-\mathbf{5}$. In contrast, the analogous rearrangement starting with $\mathrm{H}$-abstraction from the $\mathrm{Ir}-\mathrm{CH}_{2}$ terminus would produce the diastereomer $\boldsymbol{t} \mathbf{- 5}$.

The distribution of the deuterium labels depicted in Scheme 6 was inferred from ${ }^{1} \mathrm{H}$ NMR spectroscopic analysis based on the expected isotopic distribution shown in Scheme 5. These results confirmed that not unreasonably, there is a competition between abstraction of the hydride from the two alkyl positions, $\mathrm{Ir}-\mathrm{CH}_{2}$ and $\mathrm{Ir}-\mathrm{CH}_{3}$, with the latter, that leads to the kinetic isomer $\boldsymbol{k} \mathbf{- 5}$, being preferred. The reactions were carried out at $25{ }^{\circ} \mathrm{C}$ and spectroscopic analysis was acquired immediately to prevent $\mathrm{H} / \mathrm{D}$ scrambling due to isomerization reactions. Primary kinetic isotopic effects were noticeable in these experiments: hydride abstraction from the protio isotopologue, 1-Me (Scheme 2) yielded a 90:10 mixture of $\boldsymbol{k - 5}: \boldsymbol{t}-\mathbf{5}$ (70\% overall yield), whereas the use of $\left[\boldsymbol{D}_{11}\right]-\mathbf{1}-\mathbf{M e}$ increased the ratio of the $\boldsymbol{k}$-isomer (abstraction from $\mathrm{Ir}-\mathrm{CH}_{3}$ ) at the expense of the $\boldsymbol{t}$-isomer (abstraction from $\mathrm{Ir}-\mathrm{CD}_{2}$ ), with a $\boldsymbol{k}: \boldsymbol{t}$ proportion of $c a$. 97:3. The opposite effect was found when $\mathbf{1 - C D _ { 3 }}$ underwent hydrogen abstraction $(\boldsymbol{k}: \boldsymbol{t} \approx 75: 25)$.

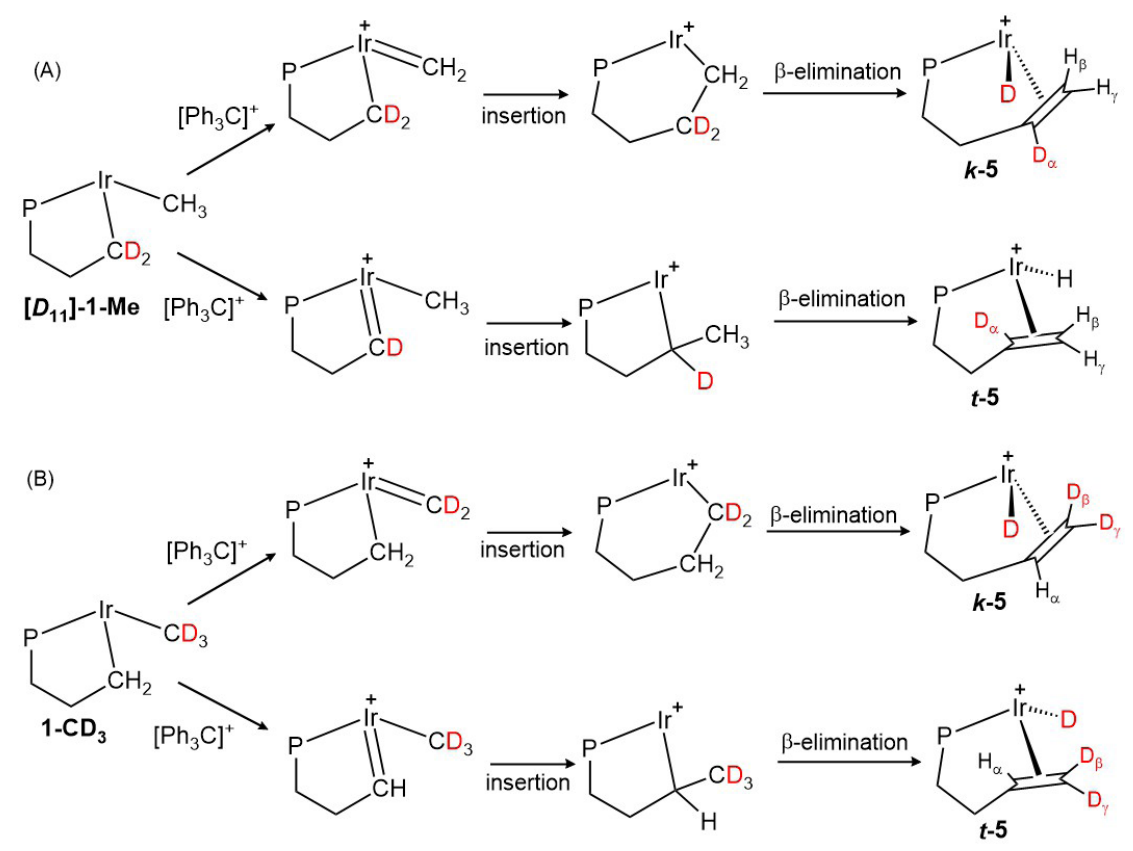

Scheme 5. Expected deuteration patterns of the products (5) resulting from $\mathrm{Ir}-\mathrm{CH}_{3}$ or $\mathrm{Ir}-\mathrm{CH}_{2}$ hydride abstraction of isotopologues $\left[\boldsymbol{D}_{11}\right]-1-\mathrm{Me}$ (A) and $1-\mathrm{CD}_{3}(\mathrm{~B})$. Molecular structures have been simplified for clarity. 
(A)

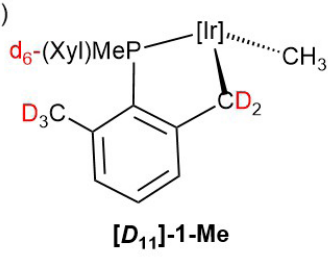

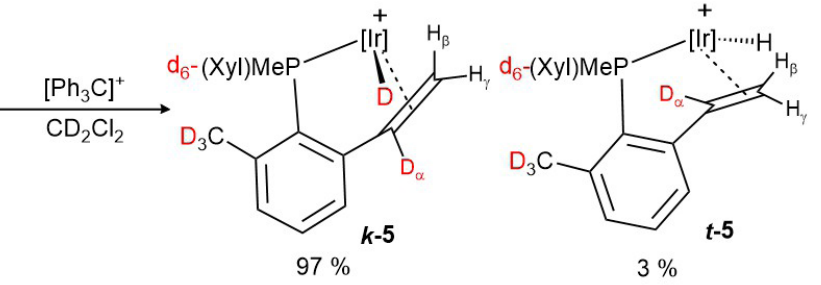

(B)<smiles>Cc1cccc2c1P[In](C(C)(C)C)C2</smiles>

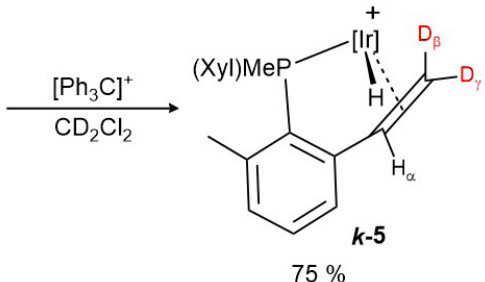

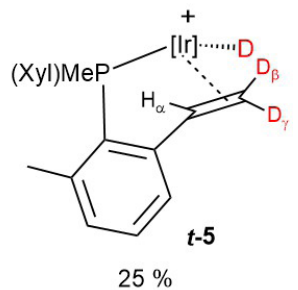

Scheme 6. Reaction of trityl cation with deuterated compounds $\left[\boldsymbol{D}_{11}\right]-1-\mathrm{Me}(\mathrm{A})$ and $1-\mathrm{CD}_{3}(\mathrm{~B})$.

\section{Reaction of $1^{+}$with Diazocompounds}

As an extension of these studies we investigated the reaction of $\mathbf{1}^{+}$with two diazocompounds (Scheme 7) as carbene transfer reagents, with the aim of disclosing other $\mathrm{C}$ - $\mathrm{C}$ coupling reactions between alkyl and carbene fragments. Indeed, addition of either $\mathrm{EDA}$ (EDA = ethyldiazoacetate, $\mathrm{N}_{2} \mathrm{CHCOOEt}$ ) or (trimethylsilyl)diazomethane $\left(\mathrm{N}_{2} \mathrm{CHSiMe}_{3}\right)$ resulted in the expected $\mathrm{C}-\mathrm{C}$ coupling reaction that led to complexes $\mathbf{7}$ and $\mathbf{8}$, respectively. These transformations could be regarded as models for related catalytic $\mathrm{C}-\mathrm{C}$ coupling processes such as the $\mathrm{C} 1$ polymerization of diazocompounds[32] and other relevant transformations that involve the formation of new $\mathrm{C}-\mathrm{C}$ bonds. [33] The new compounds were obtained as mixtures of cis and trans isomers of the newly formed olefinic ligand. The identification of geometric isomers was achieved with the aid of 2D-COSY and NOESY NMR experiments. A slight preference for the trans isomer was found in the formation of both 7 and 8. In fact, the proportion of trans-7 increased to $\mathrm{ca}$. $75 \%$ when the reaction of $\mathbf{1}^{+}$with EDA was effected at $-80{ }^{\circ} \mathrm{C}$, and then the mixture allowed to reach slowly room temperature. No intermediates were detected by low-temperature ${ }^{1} \mathrm{H}$ NMR monitoring, but in view of the chemistry already discussed and our prior studies on related systems, the reaction involved, in all probability, highly reactive cationic alkylidene species resulting from carbene transfer from the diazocompound to the vacant site of $\mathbf{1}^{+}$following a change in the coordination of the benzylic terminus[20b] from $\eta^{3}$ to $\eta^{1}$. The resulting metal carbene subsequently rearranged by migratory insertion of the Ir$\mathrm{CH}_{2}$ fragment and $\beta-\mathrm{H}$ elimination elementary steps.[34]

(A)
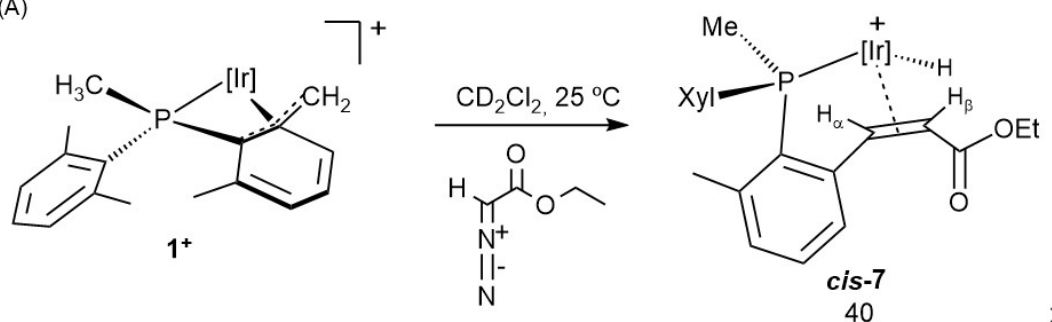

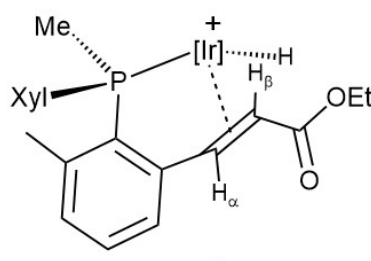

trans-7

60

(B)

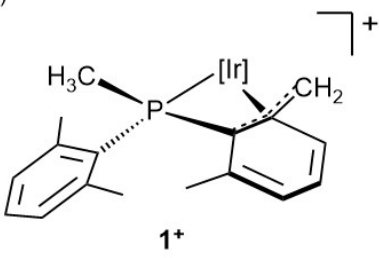

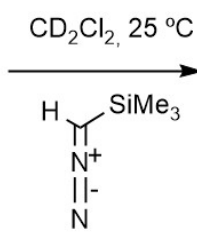

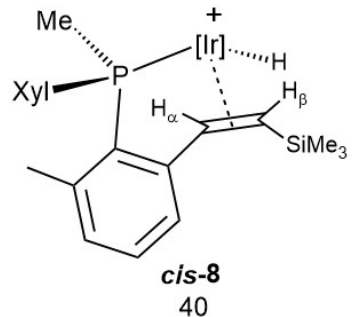

(+ other minor isomers)

Scheme 7. Reaction of $1^{+}$with diazocompounds EDA (A) and $\mathrm{N}_{2} \mathrm{CHSiMe}_{3}$ (B). 
Compounds 7 and 8 exhibit strongly deshielded, highly characteristic ${ }^{1} \mathrm{H}$ NMR doublets between -15 and -17 ppm due to the iridium hydride ligands, with a two-bond coupling to the phosphorous nucleus of around $29 \mathrm{~Hz}$. Their corresponding infrared bands appear between 2150 and $2175 \mathrm{~cm}^{-1}$. Two doublets at 4.73 and $3.72 \mathrm{ppm}$ in the ${ }^{1} \mathrm{H}$ NMR spectrum of trans-7 are due to olefinic protons $\mathrm{H}_{\alpha}$ and $\mathrm{H}_{\beta}$, respectively, and exhibit a three-bond coupling constant of $9.3 \mathrm{~Hz}$. The corresponding ${ }^{13} \mathrm{C}\left\{{ }^{1} \mathrm{H}\right\}$ NMR signals for $\mathrm{CH}_{\alpha}$ and $\mathrm{CH}_{\beta}$ appear at 59.5 and 40.9 ppm, respectively, the former presenting a small coupling to phosphorous of $4 \mathrm{~Hz}$. The methylene protons of the ethoxy group $\left(\mathrm{OCH}_{2} \mathrm{CH}_{3}\right)$ are diastereotopic and give two multiplets at 4.29 and $4.14 \mathrm{ppm}$, whereas the methyl group appears as a triplet $\left({ }^{3} J_{\mathrm{HH}}=7.1 \mathrm{~Hz}\right)$ at $1.32 \mathrm{ppm} .{ }^{1} \mathrm{H}$ and ${ }^{13} \mathrm{C}\left\{{ }^{1} \mathrm{H}\right\}$ NMR data due to cis-7 are not dissimilar to those of the trans isomer (see Experimental Section for details). Similar resonances are measured for compounds 8 . The olefinic protons of cis-8 exhibit ${ }^{1} \mathrm{H}$ NMR doublets at $4.85\left(\mathrm{H}_{\alpha}\right)$ and $2.38\left(\mathrm{H}_{\beta}\right)$ ppm, with a threebond coupling constant of $11.7 \mathrm{~Hz}$. The corresponding ${ }^{13} \mathrm{C}\left\{{ }^{1} \mathrm{H}\right\}$ peaks appear at $71.6\left(\mathrm{~d},{ }^{2} J_{\mathrm{CP}}=4 \mathrm{~Hz}\right)$ and $44.4(\mathrm{~s})$ due to $\mathrm{CH}_{\alpha}$ and $\mathrm{CH}_{\beta}$, respectively. The trimethylsilyl group is responsible for a singlet in the ${ }^{1} \mathrm{H}$ NMR spectrum at $0.13 \mathrm{ppm}$ and comparable data are found for the related trans isomer. Two-dimensional homonuclear and heteronuclear NMR experiments further support the formulations depicted in Scheme 8 for compounds 7 and 8.

We performed an additional experiment to corroborate the proposed nature of compounds $\mathbf{7}$ and $\mathbf{8}$ and in support of our mechanistic suggestion of alkyl migratory insertion into an alkylidene functionality as the key C-C coupling step. Thus, we attempted the synthesis of the trimethylsilyl-substituted alkene complex 8 by $\alpha$-hydride abstraction by $\mathrm{Ph}_{3} \mathrm{C}^{+}$from alkyl compound 1- $\mathrm{CH}_{2} \mathrm{SiMe}_{3}$ (Scheme 8), earlier reported by our group. [18b]The reaction proved to be more complex than foreseen and led to a mixture of compounds encompassing several iridium hydrides. Among the latter, the main species (ca. $30 \%$ overall yield by NMR) was, however, the expected complex 8 (Scheme 8), therefore corroborating the advanced hypothesis regarding the participation of reactive iridium alkylidenes in the formation of complexes $\mathbf{7}$ and $\mathbf{8}$ as in Scheme 7.

\section{Conclusions}

Five-membered iridacycles that contain the bulky phosphine $\mathrm{PMe}(\mathrm{Xyl})_{2}$ metalated at one of its benzylic $\gamma-\mathrm{CH}$ bonds and further stabilized by metal coordination to $\eta^{5}-\mathrm{C}_{5} \mathrm{Me}_{5}$, readily generate uncommon cationic $\mathrm{Ir}(\mathrm{III})$ alkylidenes by electrophilic attack of $\mathrm{Ph}_{3} \mathrm{C}^{+}$. Hampering participation of the resulting iridium-carbene bond in migratory insertion reactions permitted isolation of cationic Ir(III) metal acyclicalkylidenes $\mathbf{3}$ and $\mathbf{4}$ of remarkable thermal stability, while on the contrary, the presence of an additional hydride or methyl ligand promoted further reactivity, in the latter case with formation of a new C-C bond. From these studies, which are summarized in Schemes 1 and 2, and from deuterium labeling experiments collected in Schemes 4-6, it can be concluded that $\mathrm{Ph}_{3} \mathrm{C}^{+}$is capable to effect electrophilic attack at $\alpha$ and $\beta$ positions of carbon-based ligands in our complex precursors, as well as at Ir-H sites.

\section{Acknowledgments}

Financial support from Spanish Ministry of Science (Projects CTQ2013-42501-P, CTQ2014-51912-REDC and CTQ-201452769-C3-3-R) and the Junta de Andalucía (Grant FQM-119 and project P09-FQM-4832 and FQM-2126) is gratefully acknowledged. J.C. thanks the EU 7th Framework Program, Marie Skłodowska-Curie actions (COFUND, Grant Agreement no. 267226) and Junta de Andalucía for a Talentia Postdoc Fellowship.

\section{Experimental Section}

General considerations. All preparations and manipulations were carried out under oxygen free argon or nitrogen, using conventional Schlenk techniques and, when specified, at low temperature. Solvents were rigorously dried and degassed before use. Microanalyses were performed by the Microanalytical Service of the Instituto de Investigaciones Químicas (Sevilla, Spain). Infrared spectra were recorded on a Bruker Vector 22
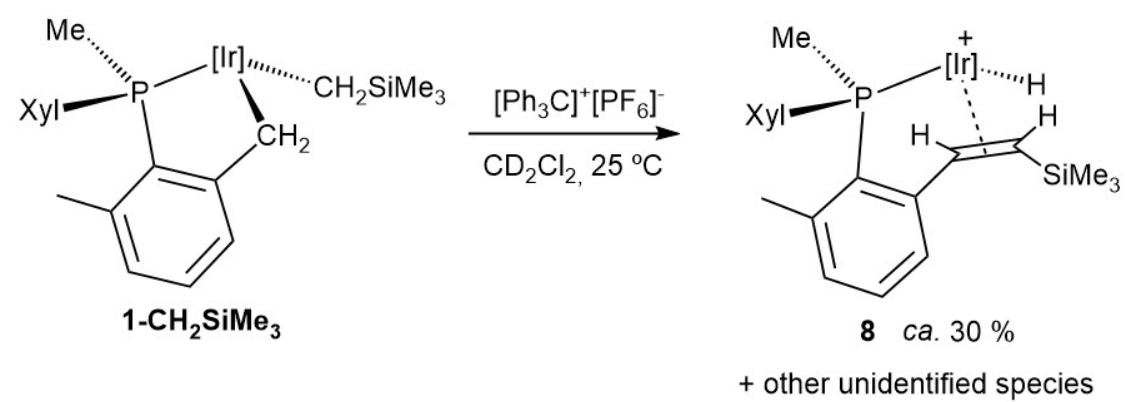

Scheme 8. Reaction of 1-CH $\mathrm{CH}_{2} \mathrm{SiMe}_{3}$ with $\left[\mathrm{Ph}_{3} \mathrm{C}\right]^{+}\left[\mathrm{PF}_{6}\right]^{-}$. 
spectrometer. Solution NMR spectra were recorded on Bruker Avance DPX-300, Avance DRX-400, Avance DRX-500, and 400 Ascend/R spectrometers. The ${ }^{1} \mathrm{H}$ and ${ }^{13} \mathrm{C}$ resonances of the solvent were used as the internal standard and the chemical shifts are reported relative to TMS, while ${ }^{31} \mathrm{P}$ was referenced to external $\mathrm{H}_{3} \mathrm{PO}_{4}$. Allaromatic couplingsin the ${ }^{1} \mathrm{H}$ NMR spectra are of $c a .7 .5 \mathrm{~Hz}$. The crystal structures were determined in a Bruker-Nonius, X8Kappa diffractometer. 1-H, 1-Cl,1-Me and 1-CH $\mathrm{CH}_{2} \mathrm{SiMe}_{3}$ were prepared according to literature methods. ${ }^{[} 18^{]}$Other chemicals were commercially available and used as received. CCDC nos. 1498592-1498595 contain the crystallographic data for compounds $3, \mathbf{4}, \boldsymbol{k}-\mathbf{5}$ and $\boldsymbol{t} \mathbf{- 5}$. These data can be obtained free of charge from The Cambridge Crystallographic Data Centre via www.ccdc.cam.ac.uk/data_request/cif.

Compound $1-\mathbf{C D}_{3}$. It was synthesized by a modified procedure from that employed for the preparation of $\mathbf{1 - M e},[18]$ consisting in the addition of a diethyl ether solution of $\mathrm{Mg}\left(\mathrm{CD}_{3}\right) \mathrm{I}(1 \mathrm{M}$, $50 \mu \mathrm{L})$ to a $\mathrm{CH}_{2} \mathrm{Cl}_{2}$ solution of $\mathbf{1}^{+}(50 \mathrm{mg}, 0.035 \mathrm{mmol})$. The reaction mixture was stirred at room temperature for $15 \mathrm{~min}$, then the volatiles were removed under vacuum and the residue extracted with pentane. The solvent was evaporated to dryness to give compound $\mathbf{1 -} \mathbf{C D}_{\mathbf{3}}$ as a pale yellow powder (13 $\mathrm{mg}, 62$ $\%)$. Spectroscopic data matched those of 1-Me except for the ${ }^{1} \mathrm{H}$ NMR resonance due to $\mathrm{Ir}-\mathrm{CH}_{3}$ that was absent in the case of 1-CD 3 .

Compound 3. A solid mixture of 1-Cl (50 mg, $0.08 \mathrm{mmol})$ and $\left[\mathrm{Ph}_{3} \mathrm{C}\right]^{+}\left[\mathrm{PF}_{6}\right]^{-}(32 \mathrm{mg}, 0.08 \mathrm{mmol})$ was dissolved in $\mathrm{CH}_{2} \mathrm{Cl}_{2}(3$ $\mathrm{mL}$ ) at $-20{ }^{\circ} \mathrm{C}$ and stirred at room temperature for 5 minutes, resulting in a dark green solution. Addition of pentane $(10 \mathrm{~mL})$ led to the precipitation of a green solid which was washed with diethyl ether to yield complex 3 as a dark green powder (54 mg, $87 \%$ ). Suitable crystals for X-ray analysis were obtained by slow diffusion of pentane into a dichloromethane solution of the compound. Elemental analysis calcd. for $\mathrm{C}_{27} \mathrm{H}_{39} \mathrm{ClF}_{6} \mathrm{IrP}_{2}$ : C, 42.27; H, 5.12;found: C, 42.3; H, 4.8. ${ }^{1} \mathrm{H}$ NMR(400 MHz, $\left.\mathrm{CD}_{2} \mathrm{Cl}_{2}, 25^{\circ} \mathrm{C}\right) \delta: 16.61\left(\mathrm{~d}, 1 \mathrm{H},{ }^{3} J_{\mathrm{HP}}=0.9 \mathrm{~Hz}, \mathrm{Ir}=\mathrm{CH}\right), 8.18(\mathrm{~d}$, $\left.1 \mathrm{H}, \mathrm{H}_{\mathrm{a}}\right), 7.87\left(\mathrm{dd}, 1 \mathrm{H},{ }^{4} J_{\mathrm{HP}}=3.4 \mathrm{~Hz}, \mathrm{H}_{\mathrm{c}}\right), 7.61\left(\mathrm{td}, 1 \mathrm{H},{ }^{5} J_{\mathrm{HP}}=\right.$

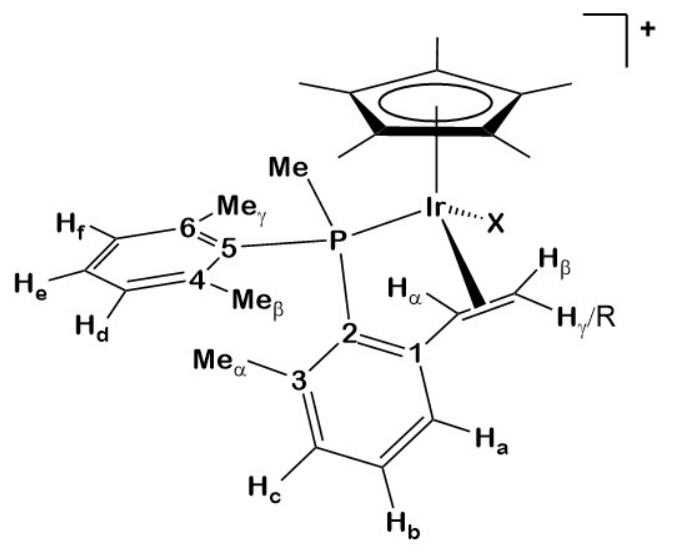

Fig. 7. Labeling scheme used for ${ }^{1} \mathrm{H}$ and ${ }^{13} \mathrm{C}\left\{{ }^{1} \mathrm{H}\right\}$ NMR assignments. $\left.2.4 \mathrm{~Hz}, \mathrm{H}_{\mathrm{b}}\right), 7.40\left(\mathrm{td}, 1 \mathrm{H},{ }^{5} J_{\mathrm{HP}}=2.1 \mathrm{~Hz}, \mathrm{H}_{\mathrm{e}}\right), 7.33,7.06(\mathrm{~m}, 1$ $\mathrm{H}$ each, $\left.\mathrm{H}_{\mathrm{d}}, \mathrm{H}_{\mathrm{f}}\right), 2.56\left(\mathrm{~d}, 3 \mathrm{H},{ }^{2} J_{\mathrm{HP}}=11.0 \mathrm{~Hz}, \mathrm{PMe}\right), 2.55,1.32$ (s, $3 \mathrm{H}$ each, $\mathrm{Me}_{\beta}, \mathrm{Me}_{\gamma}$ ), 2.44 (s, $3 \mathrm{H}, \mathrm{Me}_{\alpha}$ ), 1.66 (d, $15 \mathrm{H},{ }^{4} J_{\mathrm{HP}}$ $\left.=1.8 \mathrm{~Hz}, \mathrm{C}_{5} \mathrm{Me}_{5}\right) \cdot{ }^{13} \mathrm{C} \mathrm{NMR}\left(100 \mathrm{MHz}, \mathrm{CD}_{2} \mathrm{Cl}_{2}, 25^{\circ} \mathrm{C}\right) \delta: 262.4$ $\left({ }^{1} J_{\mathrm{CH}}=153 \mathrm{~Hz}, \mathrm{Ir}=\mathrm{CH}\right), 165.2\left(\mathrm{~d},{ }^{2} J_{\mathrm{CP}}=29 \mathrm{~Hz}, \mathrm{C}_{1}\right), 145.6\left(\mathrm{C}_{3}\right)$, $143.8\left(\mathrm{~d},{ }^{1} J_{\mathrm{CP}}=61 \mathrm{~Hz}, \mathrm{C}_{2}\right), 142.4\left(\mathrm{~d},{ }^{2} J_{\mathrm{CP}}=11 \mathrm{~Hz}, \mathrm{C}_{4 / 6}\right), 140.9$ $\left(\mathrm{d},{ }^{2} J_{\mathrm{CP}}=8 \mathrm{~Hz}, \mathrm{C}_{4 / 6}\right), 139.1\left(\mathrm{~d},{ }^{3} J_{\mathrm{CP}}=8 \mathrm{~Hz}, \mathrm{CH}_{\mathrm{c}}\right), 135.2\left(\mathrm{CH}_{\mathrm{b}}\right)$, $132.5\left(\mathrm{~d},{ }^{4} J_{\mathrm{CP}}=2 \mathrm{~Hz}, \mathrm{CH}_{\mathrm{e}}\right), 131.9,131.0\left(\mathrm{~d},{ }^{3} J_{\mathrm{CP}}=10 \mathrm{~Hz}, \mathrm{CH}_{\mathrm{d}}\right.$, $\left.\mathrm{CH}_{\mathrm{f}}\right), 131.4\left(\mathrm{~d},{ }^{3} J_{\mathrm{CP}}=13 \mathrm{~Hz}, \mathrm{CH}_{\mathrm{a}}\right), 121.0\left(\mathrm{~d},{ }^{1} J_{\mathrm{CP}}=54 \mathrm{~Hz}, \mathrm{C}_{5}\right)$, $108.7\left(C_{5} \mathrm{Me}_{5}\right), 25.6,24.0\left(\mathrm{~d},{ }^{3} J_{\mathrm{CP}}=6 \mathrm{~Hz}, \mathrm{Me}_{\beta}, \mathrm{Me} \gamma\right), 20.4(\mathrm{~d}$, $\left.{ }^{3} J_{\mathrm{CP}}=2 \mathrm{~Hz}, \mathrm{Me}_{\alpha}\right), 14.5\left(\mathrm{~d},{ }^{1} J_{\mathrm{CP}}=42 \mathrm{~Hz}, \mathrm{PMe}\right), 8.8$ $\left(\mathrm{C}_{5} M e_{5}\right) .{ }^{31} \mathrm{P}\left\{{ }^{1} \mathrm{H}\right\} \mathrm{NMR}\left(160 \mathrm{MHz}, \mathrm{CD}_{2} \mathrm{Cl}_{2}, 25{ }^{\circ} \mathrm{C}\right) \delta: 20.8$.

Compound 4. A solution of $\left[\mathrm{Ph}_{3} \mathrm{C}\right]^{+}\left[\mathrm{B}\left(\mathrm{C}_{6} \mathrm{~F}_{5}\right)_{4}\right]^{-}(40 \mathrm{mg}, 0.04)$ in dichloromethane $(0.5 \mathrm{~mL})$ was added under argon over a solution of $2(25 \mathrm{mg}, 0.04)$ in the same solvent at $-60^{\circ} \mathrm{C}$. The solution turned dark-red immediately and, after addition of pentane, compound $\mathbf{4}$ precipitated as a red powder. Washing with pentane and drying under vacuum gave alkylidene $\mathbf{4}$ in $60 \%$ yield $(31 \mathrm{mg}$ ). Crystals suitable for X-ray analysis were obtained by slow diffusion of pentane into a concentrated dichloromethane solution of the complex, however, due to its instability toward moisture and oxygen, reliable microanalytical data could not be obtained. ${ }^{1} \mathrm{H} \mathrm{NMR}\left(400 \mathrm{MHz}, \mathrm{CD}_{2} \mathrm{Cl}_{2}, 25^{\circ} \mathrm{C}\right)$ $\delta: 14.9(\mathrm{~s}, 1 \mathrm{H}, \mathrm{Ir}=\mathrm{CH}), 7.76\left(\mathrm{~d}, 1 \mathrm{H}, \mathrm{H}_{\mathrm{a}}\right), 7.55\left(\mathrm{~m}, 2 \mathrm{H}, \mathrm{H}_{\mathrm{c}}, \mathrm{H}_{\mathrm{e}}\right)$, 7.40, $7.25\left(\mathrm{~m}, 1 \mathrm{H}\right.$ each, $\left.\mathrm{H}_{\mathrm{d}}, \mathrm{H}_{\mathrm{f}}\right), 7.35\left(\mathrm{~m}, 1 \mathrm{H}, \mathrm{H}_{\mathrm{b}}\right), 3.40(\mathrm{~d}, 1$ $\left.\mathrm{H},{ }^{2} J_{\mathrm{HH}}=8.6 \mathrm{~Hz}, \operatorname{IrCHH}\right), 3.33\left(\mathrm{~d}, 1 \mathrm{H},{ }^{2} J_{\mathrm{HH}}=8.6 \mathrm{~Hz}, \operatorname{IrCH} H\right)$, 2.91, 2.16 (s, $3 \mathrm{H}$ each, $\mathrm{Me}_{\beta}, \mathrm{Me}_{\gamma}$ ), 2.27 (s, $3 \mathrm{H}, \mathrm{Me}_{\alpha}$ ), 1.96 (d, $\left.15 \mathrm{H},{ }^{4} J_{\mathrm{HP}}=1.8 \mathrm{~Hz}, \mathrm{C}_{5} \mathrm{Me}_{5}\right) .{ }^{13} \mathrm{C} \mathrm{NMR}\left(125 \mathrm{MHz}, \mathrm{CD}_{2} \mathrm{Cl}_{2},-60\right.$ $\left.{ }^{\circ} \mathrm{C}\right) \delta: 243.7\left(\mathrm{~d},{ }^{2} J_{\mathrm{CP}}=28 \mathrm{~Hz}, \mathrm{Ir}=\mathrm{CH}\right), 162.4\left(\mathrm{~d},{ }^{2} J_{\mathrm{CP}}=27 \mathrm{~Hz}\right.$, $\left.\mathrm{C}_{1}\right), 144.8\left(\mathrm{~d},{ }^{2} J_{\mathrm{CP}}=4 \mathrm{~Hz}, \mathrm{C}_{3}\right), 143.9\left(\mathrm{~d},{ }^{2} J_{\mathrm{CP}}=16 \mathrm{~Hz}, \mathrm{C}_{4 / 6}\right)$, $141.5\left(\mathrm{~d},{ }^{2} J_{\mathrm{CP}}=6 \mathrm{~Hz}, \mathrm{C}_{4 / 6}\right), 134.4\left(\mathrm{CH}_{\mathrm{b}}\right.$, overlapped with $\mathrm{BAr}_{4}{ }^{-}$ ), $133.3\left(\mathrm{~d},{ }^{3} J_{\mathrm{CP}}=10 \mathrm{~Hz}, \mathrm{CH}_{\mathrm{c}}\right), 129.8\left(\mathrm{CH}_{\mathrm{e}}\right), 129.1,128.4(\mathrm{~d}$, $\left.{ }^{3} J_{\mathrm{CP}}=11 \mathrm{~Hz}, \mathrm{CH}_{\mathrm{d}}, \mathrm{CH}_{\mathrm{f}}\right), 127.2\left(\mathrm{~d},{ }^{3} J_{\mathrm{CP}}=17 \mathrm{~Hz}, \mathrm{CH}_{\mathrm{a}}\right), 111.1(\mathrm{~d}$, $\left.{ }^{1} J_{\mathrm{CP}}=69 \mathrm{~Hz}, \mathrm{C}_{5}\right), 101.9\left(C_{5} \mathrm{Me}_{5}\right), 24.4,19.2\left(\mathrm{~d},{ }^{3} J_{\mathrm{CP}}=6,14 \mathrm{~Hz}\right.$, $\left.\mathrm{Me}_{\beta}, \mathrm{Me}_{\gamma}\right), 19.0\left(\mathrm{~d},{ }^{3} J_{\mathrm{CP}}=5 \mathrm{~Hz}, \mathrm{Me}_{\alpha}\right), 13.7\left(\mathrm{~d},{ }^{1} J_{\mathrm{CP}}=45 \mathrm{~Hz}\right.$, $\left.\mathrm{IrCH}_{2}\right), 8.5\left(\mathrm{C}_{5} \mathrm{Me}_{5}\right)$. Signal corresponding to $\mathrm{C}_{2}$ was not identified. ${ }^{31} \mathrm{P}\left\{{ }^{1} \mathrm{H}\right\} \mathrm{NMR}\left(160 \mathrm{MHz}, \mathrm{CD}_{2} \mathrm{Cl}_{2}, 25^{\circ} \mathrm{C}\right) \delta$ : -13.1 .

Reaction of 1-Me with $\left[\mathrm{Ph}_{3} \mathrm{C}\right]^{+}\left[\mathrm{B}\left(\mathrm{C}_{6} \mathrm{~F}_{5}\right)_{4}\right]^{-}(\mathrm{Compounds} \mathbf{5}$ and 6). A solution of $\left[\mathrm{Ph}_{3} \mathrm{C}\right]^{+}\left[\mathrm{B}\left(\mathrm{C}_{6} \mathrm{~F}_{5}\right)_{4}\right]^{-}(92 \mathrm{mg}, 0.10 \mathrm{mmol})$ in $\mathrm{CH}_{2} \mathrm{Cl}_{2}(1 \mathrm{~mL})$ was added at $0{ }^{\circ} \mathrm{C}$ under argon over a $\mathrm{CH}_{2} \mathrm{Cl}_{2}$ solution of 1-Me $(60 \mathrm{mg}, 0.10 \mathrm{mmol})$ placed in a Schlenk flask. The reaction mixture was stirred at room temperature for 30 min and analyzed by ${ }^{31} \mathrm{P}\left\{{ }^{1} \mathrm{H}\right\} \mathrm{NMR}$, which showed complete conversion of the methyl complex 1-Me into a ca.63:7:30 mixture of compounds $\boldsymbol{k - 5}: \boldsymbol{t}-\mathbf{5}: \mathbf{6}$. Heating the solution at $50{ }^{\circ} \mathrm{C}$ for 12 hours resulted in complete isomerization of $\boldsymbol{k}-\mathbf{5}$ into $\boldsymbol{t}-\mathbf{5}$, while 6 remained unaltered. The solvent was removed under vacuum and the residue washed with diethyl ether. Compounds 5 and $\mathbf{6}$ were purified by crystallization from $\mathrm{CH}_{2} \mathrm{Cl}_{2} /$ pentane to obtain a mixture of both isomers in $56 \%$ overall yield (72 mg); however all attempts to isolate the individual complexes in a pure state were unsuccesful. Spectroscopic data obtained from mixtures of these isomers, are detailed below. Elemental analysis for the mixture of isomers calcd. for $\mathrm{C}_{52} \mathrm{H}_{42} \mathrm{BF}_{20} \mathrm{IrP}$ : C, 
48.76; H, 3.31. Found: C, 48.9; H, 3.5.Compound $\boldsymbol{t}-5$ : ${ }^{1} \mathrm{H}$ NMR $\left(500 \mathrm{MHz}, \mathrm{CD}_{2} \mathrm{Cl}_{2}, 25^{\circ} \mathrm{C}\right) \delta: 7.47\left(\mathrm{~d}, 1 \mathrm{H}, \mathrm{H}_{\mathrm{a}}\right), 7.36-$ $7.23\left(\mathrm{~m}, 3 \mathrm{H}, \mathrm{CH}_{\mathrm{Xyl}}\right), 7.07-6.98\left(\mathrm{~m}, 2 \mathrm{H}, \mathrm{CH}_{\mathrm{Xyl}}\right), 4.27$ (dd, 1 $\left.\mathrm{H},{ }^{3} J_{\mathrm{HH}}=10.5,{ }^{3} J_{\mathrm{HH}}=8.6 \mathrm{~Hz}, \mathrm{H}_{\alpha}\right), 2.83\left(\mathrm{dt}, 1 \mathrm{H},{ }^{3} J_{\mathrm{HH}}=10.5\right.$, $\left.{ }^{2} J_{\mathrm{HH}}={ }^{3} J_{\mathrm{HP}}=2.4 \mathrm{~Hz}, \mathrm{H}_{\gamma}\right), 2.64\left(\mathrm{dd}, 1 \mathrm{H},{ }^{3} J_{\mathrm{HH}}=8.6,{ }^{2} J_{\mathrm{HH}}=2.4\right.$ $\left.\mathrm{Hz}, \mathrm{H}_{\beta}\right), 2.59,1.45\left(\mathrm{~s}, 3 \mathrm{H}\right.$ each, $\left.\mathrm{Me}_{\beta}, \mathrm{Me}_{\gamma}\right), 2.46\left(\mathrm{~d}, 3 \mathrm{H},{ }^{2} J_{\mathrm{HP}}=\right.$ $9.0 \mathrm{~Hz}, \mathrm{PMe}), 1.91\left(\mathrm{~s}, 3 \mathrm{H}, \mathrm{Me}_{\alpha}\right), 1.73\left(\mathrm{~d}, 15 \mathrm{H},{ }^{4} J_{\mathrm{HP}}=1.7 \mathrm{~Hz}\right.$, $\left.\mathrm{C}_{5} \mathrm{Me}_{5}\right),-15.77\left(\mathrm{~d}, 1 \mathrm{H},{ }^{2} J_{\mathrm{HP}}=30.1 \mathrm{~Hz}, \mathrm{IrH}\right) .{ }^{13} \mathrm{C}$ NMR $(125$ $\left.\mathrm{MHz}, \mathrm{CD}_{2} \mathrm{Cl}_{2}, 25^{\circ} \mathrm{C}\right) \delta: 146.9\left(\mathrm{~d},{ }^{2} J_{\mathrm{CP}}=23 \mathrm{~Hz}, \mathrm{C}_{1}\right), 141.8\left(\mathrm{C}_{3}\right)$, $141.6,140.2\left(\mathrm{~d},{ }^{2} J_{\mathrm{CP}}=9 \mathrm{~Hz}, \mathrm{C}_{4}, \mathrm{C}_{6}\right), 136.8\left(\mathrm{~d},{ }^{1} J_{\mathrm{CP}}=61 \mathrm{~Hz}\right.$, $\left.\mathrm{C}_{2}\right), 131.8,131.5\left(\mathrm{CH}_{\mathrm{b}}, \mathrm{CH}_{\mathrm{e}}\right), 131.1,130.3\left(\mathrm{~d},{ }^{3} J_{\mathrm{CP}}=8 \mathrm{~Hz}\right.$, $\left.\mathrm{CH}_{\mathrm{d}}, \mathrm{CH}_{\mathrm{f}}\right), 130.7\left(\mathrm{~d},{ }^{3} J_{\mathrm{CP}}=8 \mathrm{~Hz}, \mathrm{CH}_{\mathrm{c}}\right), 127.0\left(\mathrm{~d},{ }^{3} J_{\mathrm{CP}}=16 \mathrm{~Hz}\right.$, $\left.\mathrm{CH}_{\mathrm{a}}\right), 123.4\left(\mathrm{~d},{ }^{1} J_{\mathrm{CP}}=52 \mathrm{~Hz}, \mathrm{C}_{5}\right), 101.0\left(C_{5} \mathrm{Me}_{5}\right), 62.7\left(\mathrm{~d},{ }^{2} J_{\mathrm{CP}}\right.$ $\left.=4 \mathrm{~Hz}, \mathrm{CH}_{\alpha}\right), 34.1\left(\mathrm{CH}_{\beta} \mathrm{H}_{\gamma}\right), 28.0\left(\mathrm{~d},{ }^{1} J_{\mathrm{CP}}=50 \mathrm{~Hz}, \mathrm{PMe}\right), 24.7$, $22.8\left(\mathrm{~d},{ }^{3} J_{\mathrm{CP}}=7 \mathrm{~Hz}, \mathrm{Me}_{\beta}, \mathrm{Me} \gamma\right), 19.9\left(\mathrm{~d},{ }^{3} J_{\mathrm{CP}}=18 \mathrm{~Hz}, \mathrm{Me}_{\alpha}\right)$, $8.4\left(\mathrm{C}_{5} M e_{5}\right) \cdot{ }^{31} \mathrm{P}\left\{{ }^{1} \mathrm{H}\right\} \quad \mathrm{NMR}\left(200 \mathrm{MHz}, \mathrm{CD}_{2} \mathrm{Cl}_{2}, 25^{\circ} \mathrm{C}\right) \delta$ : -0.1.Compound $\boldsymbol{k}-5:{ }^{1} \mathrm{H}$ NMR $\left(500 \mathrm{MHz}, \mathrm{CD}_{2} \mathrm{Cl}_{2}, 25{ }^{\circ} \mathrm{C}\right) \delta$ : $7.40\left(\mathrm{~m}, 1 \mathrm{H}, \mathrm{H}_{\mathrm{a}}\right), 7.35-7.19\left(\mathrm{~m}, 3 \mathrm{H}, \mathrm{CH}_{\mathrm{Xyl}}\right), 7.08-6.96(\mathrm{~m}$, $\left.2 \mathrm{H}, \mathrm{CH}_{\mathrm{Xyl}}\right), 4.41\left(\mathrm{t}, 1 \mathrm{H},{ }^{3} J_{\mathrm{HH}},{ }^{3} J_{\mathrm{HH}}=9.1 \mathrm{~Hz}, \mathrm{H}_{\alpha}\right), 2.67(\mathrm{~m}$, overlapped, $\mathrm{H}_{\gamma}$ ), 2.65, 1.72 (s, $3 \mathrm{H}$ each, $\mathrm{Me}_{\beta}, \mathrm{Me}_{\beta}$ ), 2.24 (d, 3 $\left.\mathrm{H},{ }^{2} J_{\mathrm{HP}}=10.2 \mathrm{~Hz}, \mathrm{PMe}\right), 2.12\left(\mathrm{t}, 1 \mathrm{H},{ }^{3} J_{\mathrm{HH}}={ }^{2} J_{\mathrm{HH}}=9,1 \mathrm{~Hz}, \mathrm{H}_{\gamma}\right)$, $1.93\left(\mathrm{~d}, 15 \mathrm{H},{ }^{4} J_{\mathrm{HP}}=1.8 \mathrm{~Hz}, \mathrm{C}_{5} \mathrm{Me}_{5}\right), 1.89\left(\mathrm{~s}, 3 \mathrm{H}, \mathrm{Me}_{\alpha}\right),-14.31$ $\left(\mathrm{d}, 1 \mathrm{H},{ }^{2} J_{\mathrm{HP}}=28.5 \mathrm{~Hz}, \mathrm{IrH}\right) .{ }^{3 \mathrm{P}}\left\{{ }^{1} \mathrm{H}\right\} \mathrm{NMR}\left(200 \mathrm{MHz}, \mathrm{CD}_{2} \mathrm{Cl}_{2}\right.$, $\left.25^{\circ} \mathrm{C}\right) \delta$ : -9.8.Compound 6: ${ }^{1} \mathrm{H} \mathrm{NMR}\left(500 \mathrm{MHz}, \mathrm{CD}_{2} \mathrm{Cl}_{2}, 25\right.$ $\left.{ }^{\circ} \mathrm{C}\right) \delta: 7.36-7.23\left(\mathrm{~m}, 4 \mathrm{H}, \mathrm{CH}_{\mathrm{Xyl}}\right), 7.07-6.98\left(\mathrm{~m}, 2 \mathrm{H}, \mathrm{CH}_{\mathrm{Xyl}}\right)$, $5.30\left(\mathrm{~d}, 1 \mathrm{H},{ }^{4} J_{\mathrm{HP}}=4.2 \mathrm{~Hz}, \mathrm{H}_{\alpha / \beta}\right), 4.54\left(\mathrm{~s}, 1 \mathrm{H}, \mathrm{H}_{\alpha / \beta}\right), 3.71(\mathrm{~d}, 1$ $\left.\mathrm{H},{ }^{2} J_{\mathrm{HH}}=13.9 \mathrm{~Hz}, \operatorname{IrCHH}\right), 2.99\left(\mathrm{~d}, 1 \mathrm{H},{ }^{2} J_{\mathrm{HH}}=13.9 \mathrm{~Hz}\right.$, $\mathrm{IrCH} H$ ), 2.69, 1.45 (s, $3 \mathrm{H}$ each, $\left.\mathrm{Me}_{\beta}, \mathrm{Me}_{\gamma}\right), 2.43\left(\mathrm{~d}, 3 \mathrm{H},{ }^{2} J_{\mathrm{HP}}\right.$ $=9.6 \mathrm{~Hz}, \mathrm{PMe}), 2.01\left(\mathrm{~s}, 3 \mathrm{H}, \mathrm{Me}_{\alpha}\right), 1.80,1.75\left(\mathrm{~d}, 3 \mathrm{H}\right.$ each, ${ }^{4} J_{\mathrm{HP}}$ $=2.8 \mathrm{~Hz}, 2 \mathrm{Cp}-\mathrm{Me}), 1.57(\mathrm{~s}, 3 \mathrm{H}, \mathrm{Cp}-\mathrm{Me}), 0.85\left(\mathrm{~d}, 3 \mathrm{H},{ }^{3} J_{\mathrm{HP}}=\right.$ $\left.2.7 \mathrm{~Hz}, \mathrm{IrCH}_{3}\right), 0.76\left(\mathrm{~d}, 3 \mathrm{H},{ }^{4} J_{\mathrm{HP}}=1.4 \mathrm{~Hz}, \mathrm{Cp}-\mathrm{Me}\right) \cdot{ }^{13} \mathrm{C}$ $\operatorname{NMR}\left(125 \mathrm{MHz}, \mathrm{CD}_{2} \mathrm{Cl}_{2}, 25^{\circ} \mathrm{C}\right) \delta: 152.7\left(\mathrm{~d},{ }^{2} J_{\mathrm{CP}}=27 \mathrm{~Hz}, \mathrm{C}_{1}\right)$, 141.5, $140.1\left(\mathrm{C}_{4} 6\right), 140.2\left(\mathrm{C}_{3}\right), 134.8\left(\mathrm{~d},{ }^{1} J_{\mathrm{CP}}=65 \mathrm{~Hz}, \mathrm{C}_{2}\right), 129.4$ $\left(\mathrm{d},{ }^{3} J_{\mathrm{CP}}=9 \mathrm{~Hz}, \mathrm{CH}_{\mathrm{c}}\right), 132.1\left(\mathrm{CH}_{\mathrm{b}}, \mathrm{CH}_{\mathrm{e}}\right), 131.2,131.0\left(\mathrm{~d},{ }^{3} J_{\mathrm{CP}}\right.$ $\left.=9 \mathrm{~Hz}, \mathrm{CH}_{\mathrm{d}}, \mathrm{CH}_{\mathrm{f}}\right), 127.5\left(\mathrm{~d},{ }^{3} J_{\mathrm{CP}}=16 \mathrm{~Hz}, \mathrm{CH}_{\mathrm{a}}\right), 124.8\left(\mathrm{~d},{ }^{1} J_{\mathrm{CP}}\right.$ $\left.=53 \mathrm{~Hz}, \mathrm{C}_{5}\right), 114.2111 .8,110.1,109.4,109.3\left(C_{5} \mathrm{Me}_{4} \mathrm{CH}_{\alpha} \mathrm{H}_{\beta}\right)$, $68.6\left(\mathrm{CH}_{\alpha} \mathrm{H}_{\beta}\right), 29.6\left(\mathrm{IrCH}_{2}\right), 25.3,24.7\left(\mathrm{~d},{ }^{3} J_{\mathrm{CP}}=6 \mathrm{~Hz}, \mathrm{Me}_{\beta}\right.$, $\mathrm{Me} \gamma), 21.0\left(\mathrm{~d},{ }^{1} J_{\mathrm{CP}}=44 \mathrm{~Hz}, \mathrm{PMe}\right), 20.1\left(\mathrm{~d},{ }^{3} J_{\mathrm{CP}}=16 \mathrm{~Hz}, \mathrm{Me}_{\alpha}\right)$, 8.2, 7.8, 6.8, $4.7\left(\mathrm{C}_{5} \mathrm{Me}_{4} \mathrm{CH}_{\alpha} \mathrm{H}_{\beta}\right),-10.9\left(\mathrm{~d},{ }^{2} J_{\mathrm{CP}}=3 \mathrm{~Hz}\right.$, $\left.\mathrm{IrCH}_{3}\right) .{ }^{31} \mathrm{P}\left\{{ }^{1} \mathrm{H}\right\}$ NMR $\left(200 \mathrm{MHz}, \mathrm{CD}_{2} \mathrm{Cl}_{2}, 25^{\circ} \mathrm{C}\right) \delta: 12.2$.

Compound 7. To a solid mixture of 1-Cl (50 mg, $0.08 \mathrm{mmol})$ and $\operatorname{NaBAr}_{\mathrm{F}}(72 \mathrm{mg}, 0.08 \mathrm{mmol})$ placed in a Schlenk flask were added $5 \mathrm{~mL}$ of $\mathrm{CH}_{2} \mathrm{Cl}_{2}$. The reaction mixture was stirred for 5 $\mathrm{min}$ at room temperature and ethyldiazoacetate $(10 \mu \mathrm{L}, 0.096$ $\mathrm{mmol}$ ) was added. The solution was filtered and the volatiles were evaporated under reduced pressure to obtain 7 (102 mg, $86 \%)$ as a pale yellow powder mixture of isomers in a ratio of $c$. 60:40. Tentative isomer assignement for each set of signals is based on 2D-NOESY analysis, since NOE cross-peaks can be found between $\mathrm{H}_{\alpha}$ and $\mathrm{H}_{\beta}$ only for the cis isomer, whereas the trans isomer presents a NOE cross-peak between $\mathrm{H}_{\alpha}$ and $\mathrm{H}_{\mathrm{a}}$, which cannot be detected in the former case. The two isomers were jointly recrystallized from a 1:2 mixture of $\mathrm{CH}_{2} \mathrm{Cl}_{2}$ : pentane. Elemental analysis for the mixture of isomerscalcd.for $\mathrm{C}_{63} \mathrm{H}_{53} \mathrm{BF}_{24} \mathrm{IrO}_{2} \mathrm{P}: \mathrm{C}, 49.39 ; \mathrm{H}, 3.49$, found: $\mathrm{C}, 49.0 ; \mathrm{H}$,
3.0.Trans-7 (60\%): IR (Nujol): v(IrH) 2175, v(CO) $1710 \mathrm{~cm}^{-}$ ${ }^{1} .{ }^{1} \mathrm{H}$ NMR $\left(400 \mathrm{MHz}, \mathrm{CD}_{2} \mathrm{Cl}_{2}, 25^{\circ} \mathrm{C}\right) \delta: 7.57\left(\mathrm{~d}, 1 \mathrm{H}, \mathrm{H}_{\mathrm{a}}\right), 7.37$, $7.30,7.08\left(\mathrm{~m}, \mathrm{H}_{\mathrm{b}-\mathrm{f}}\right.$, overlapped with an analogous signals of the minor isomer), $4.73\left(\mathrm{~d}, 1 \mathrm{H},{ }^{3} \mathrm{~J}_{\mathrm{HH}}=9.3 \mathrm{~Hz}, \mathrm{CH}_{\alpha}\right), 4.29(\mathrm{~m}, 1 \mathrm{H}$, $\left.\mathrm{OCHHCH}_{3}\right), 4.14\left(\mathrm{~m}, 1 \mathrm{H}, \mathrm{OCH} H \mathrm{CH}_{3}\right), 3.72\left(\mathrm{~d}, 1 \mathrm{H},{ }^{3} J_{\mathrm{HH}}=\right.$ $9.3 \mathrm{~Hz}, \mathrm{CH}_{\beta}$ ), 2.61, 1.46 (s, $3 \mathrm{H}$ each, $\mathrm{Me}_{\beta}, \mathrm{Me}_{\gamma}$ ), 2.56 (d, $3 \mathrm{H}$, $\left.{ }^{2} J_{\mathrm{HP}}=10.0 \mathrm{~Hz}, \mathrm{PMe}\right), 1.95\left(\mathrm{~s}, 3 \mathrm{H}, \mathrm{Me}_{\alpha}\right), 1.73\left(\mathrm{~d}, 15 \mathrm{H},{ }^{4} J_{\mathrm{HP}}=\right.$ $\left.1.7 \mathrm{~Hz}, \mathrm{C}_{5} \mathrm{Me}_{5}\right), 1.32\left(\mathrm{t}, 3 \mathrm{H},{ }^{3} J_{\mathrm{HH}}=7.1 \mathrm{~Hz}, \mathrm{OCH}_{2} \mathrm{CH}_{3}\right),-15.35$ $\left(\mathrm{d}, 1 \mathrm{H},{ }^{2} J_{\mathrm{HP}}=27.8 \mathrm{~Hz}, \mathrm{IrH}\right) .{ }^{13} \mathrm{C} \mathrm{NMR}\left(100 \mathrm{MHz}, \mathrm{CD}_{2} \mathrm{Cl}_{2}, 25\right.$ $\left.{ }^{\circ} \mathrm{C}\right) \delta: 170.0(\mathrm{CO}), 147.6\left(\mathrm{~d},{ }^{2} J_{\mathrm{CP}}=26 \mathrm{~Hz}, \mathrm{C}_{1}\right), 142.3,141.7$, 141.5, $141.1\left(\mathrm{C}_{2}, \mathrm{C}_{3}, \mathrm{C}_{4}, \mathrm{C}_{6}\right), 132.7\left(\mathrm{CH}_{\mathrm{b}}\right), 132.2\left(\mathrm{~d},{ }^{4} J_{\mathrm{CP}}=2\right.$ $\left.\mathrm{Hz}, \mathrm{CH}_{\mathrm{e}}\right), 131.5\left(\mathrm{CH}_{\mathrm{d} / \mathrm{f}}\right), 131.4\left(\mathrm{CH}_{\mathrm{c}}\right), 131.0\left(\mathrm{~d},{ }^{3} J_{\mathrm{CP}}=6 \mathrm{~Hz}\right.$, $\left.\mathrm{CH}_{\mathrm{d} / \mathrm{f}}\right), 127.1\left(\mathrm{~d},{ }^{3} J_{\mathrm{CP}}=16 \mathrm{~Hz}, \mathrm{CH}_{\mathrm{a}}\right), 122.7\left(\mathrm{~d},{ }^{1} J_{\mathrm{CP}}=56 \mathrm{~Hz}\right.$, $\left.\mathrm{C}_{5}\right), 103.1\left(C_{5} \mathrm{Me}_{5}\right), 61.7\left(\mathrm{OCH}_{2} \mathrm{CH}_{3}\right), 59.5\left(\mathrm{~d},{ }^{2} J_{\mathrm{CP}}=4 \mathrm{~Hz}\right.$, $\left.\mathrm{CH}_{\alpha}\right), 40.9\left(\mathrm{CH}_{\beta}\right), 26.5\left(\mathrm{~d},{ }^{1} J_{\mathrm{CP}}=47 \mathrm{~Hz}, \mathrm{PMe}\right), 25.0,23.7(\mathrm{~d}$, $\left.{ }^{3} J_{\mathrm{CP}}=6 \mathrm{~Hz}, \mathrm{Me}_{\beta}, \mathrm{Me}_{\gamma}\right), 20.3\left(\mathrm{~d},{ }^{3} J_{\mathrm{CP}}=6 \mathrm{~Hz}, \mathrm{Me}_{\alpha}\right), 14.5$ $\left(\mathrm{OCH}_{2} \mathrm{CH}_{3}\right), 8.8\left(\mathrm{C}_{5} \mathrm{Me}_{5}\right) .{ }^{31} \mathrm{P}\left\{{ }^{1} \mathrm{H}\right\} \mathrm{NMR}\left(160 \mathrm{MHz}, \mathrm{CD}_{2} \mathrm{Cl}_{2}, 25\right.$ $\left.{ }^{\circ} \mathrm{C}\right)$ S: 1.0.Cis-7(40 \%):IR(Nujol): v(IrH) 2150, v(CO) 1650 $\mathrm{cm}^{-1} .{ }^{1} \mathrm{H}$ NMR $\left(400 \mathrm{MHz}, \mathrm{CD}_{2} \mathrm{Cl}_{2}, 25^{\circ} \mathrm{C}\right) \delta: 7.46\left(\mathrm{~d}, 1 \mathrm{H}, \mathrm{H}_{\mathrm{a}}\right)$, 7.37, 7.30, $7.08\left(\mathrm{~m}, \mathrm{H}_{\mathrm{b}-\mathrm{f}}\right.$, overlapped with analogous signals of the major isomer), $4.67\left(\mathrm{~d}, 1 \mathrm{H},{ }^{3} J_{\mathrm{HH}}=9.1 \mathrm{~Hz}, \mathrm{CH}_{\alpha}\right), 4.02(\mathrm{~m}$, $\left.1 \mathrm{H}, \mathrm{OCH} H C H_{3}\right), 3.96\left(\mathrm{~m}, 1 \mathrm{H}, \mathrm{OCH} H \mathrm{CH}_{3}\right), 3.49\left(\mathrm{~d}, 1 \mathrm{H},{ }^{3} J_{\mathrm{HH}}\right.$ $\left.=9.1 \mathrm{~Hz}, \mathrm{CH}_{\beta}\right), 2.61,1.53$ (s, $3 \mathrm{H}$ each, $\mathrm{Me}_{\beta}, \mathrm{Me}_{\gamma}$ ), 2.50 (d, 3 $\left.\mathrm{H},{ }^{2} J_{\mathrm{HP}}=11.1 \mathrm{~Hz}, \mathrm{PMe}\right), 1.92\left(\mathrm{~s}, 3 \mathrm{H}, \mathrm{Me}_{\alpha}\right), 1.75\left(\mathrm{~d}, 15 \mathrm{H},{ }^{4} J_{\mathrm{HP}}\right.$ $\left.=1.6 \mathrm{~Hz}, \mathrm{C}_{5} \mathrm{Me}_{5}\right), 1.16\left(\mathrm{t}, 3 \mathrm{H},{ }^{3} J_{\mathrm{HH}}=7.1 \mathrm{~Hz}, \mathrm{OCH}_{2} \mathrm{CH}_{3}\right)$, $-16.39\left(\mathrm{~d}, 1 \mathrm{H},{ }^{2} J_{\mathrm{HP}}=27.8 \mathrm{~Hz}, \mathrm{IrH}\right) \cdot{ }^{13} \mathrm{C}$ NMR $(100 \mathrm{MHz}, \mathrm{CD}-$ $\left.{ }_{2} \mathrm{Cl}_{2}, 25^{\circ} \mathrm{C}\right) \delta: 172.5(\mathrm{CO}), 146.4\left(\mathrm{~d},{ }^{2} J_{\mathrm{CP}}=23 \mathrm{~Hz}, \mathrm{C}_{1}\right), 142.2$, 141.5, 141.4, $141.0\left(\mathrm{C}_{2}, \mathrm{C}_{3}, \mathrm{C}_{4}, \mathrm{C}_{6}\right), 132.4\left(\mathrm{~d},{ }^{4} J_{\mathrm{CP}}=2 \mathrm{~Hz}\right.$, $\left.\mathrm{CH}_{\mathrm{e}}\right), 132.0\left(\mathrm{CH}_{\mathrm{b}}\right), 131.6\left(\mathrm{CH}_{\mathrm{d} / \mathrm{f}}\right), 131.3\left(\mathrm{CH}_{\mathrm{c}}\right), 130.9\left(\mathrm{~d},{ }^{3} J_{\mathrm{CP}}=\right.$ $\left.6 \mathrm{~Hz}, \mathrm{CH}_{\mathrm{d} / \mathrm{f}}\right), 126.8\left(\mathrm{~d},{ }^{3} J_{\mathrm{CP}}=17 \mathrm{~Hz}, \mathrm{CH}_{\mathrm{a}}\right), 124.7\left(\mathrm{C}_{5}\right), 103.1$ $\left(C_{5} \mathrm{Me}_{5}\right), 63.9\left(\mathrm{~d},{ }^{2} J_{\mathrm{CP}}=3 \mathrm{~Hz}, \mathrm{CH}_{\alpha}\right), 61.4\left(\mathrm{OCH}_{2} \mathrm{CH}_{3}\right), 40.3$ $\left(\mathrm{CH}_{\beta}\right), 25.7\left(\mathrm{~d},{ }^{1} J_{\mathrm{CP}}=47 \mathrm{~Hz}, \mathrm{PMe}\right), 25.6,23.4\left(\mathrm{~d},{ }^{3} J_{\mathrm{CP}}=5 \mathrm{~Hz}\right.$, $\left.8 \mathrm{~Hz}, \mathrm{Me}_{\beta}, \mathrm{Me}_{\gamma}\right), 20.1\left(\mathrm{~d},{ }^{3} \mathrm{~J}_{\mathrm{CP}}=6 \mathrm{~Hz}, \mathrm{Me}_{\alpha}\right), 14.0\left(\mathrm{OCH}_{2} \mathrm{CH}_{3}\right)$, $8.8\left(\mathrm{C}_{5} M e_{5}\right) .{ }^{31} \mathrm{P}\left\{{ }^{1} \mathrm{H}\right\} \operatorname{NMR}\left(160 \mathrm{MHz}, \mathrm{CD}_{2} \mathrm{Cl}_{2}, 25^{\circ} \mathrm{C}\right) \delta: 3.1$.

Compound 8. To a solid mixture of 1-Cl (50 mg, $0.081 \mathrm{mmol})$ and $\mathrm{NaBAr}_{\mathrm{F}}(72 \mathrm{mg}, 0.081 \mathrm{mmol})$ placed in a Schlenk flask 3 $\mathrm{mL}$ of $\mathrm{CH}_{2} \mathrm{Cl}_{2}$ were added at $-20^{\circ} \mathrm{C}$. After stirring for $10 \mathrm{~min}$, a solution of $\mathrm{N}_{2} \mathrm{CHSiMe}_{3}(2 \mathrm{M}$ in hexanes, $50 \mu \mathrm{L}$ ) was added at this temperature and the reaction allowed to warm up to $25^{\circ} \mathrm{C}$ and additionally stirred for 1 hour. The solution was filtered and the volatiles were removed under vacuum to give a pale yellow foam which was washed with pentane. ${ }^{1} \mathrm{H}$ and ${ }^{31} \mathrm{P}\left\{{ }^{1} \mathrm{H}\right\}$ NMR spectroscopic analysis of the crude showed four different products in a ratio of $c a$. 53:40:4:3, all of which exhibited characteristic Ir-H resonances in the ${ }^{1} \mathrm{H}$ NMR spectrum. The two major species were identified as the trans (53\%) and cis (40\%) isomers. However, only cis-8 was isolated as a single species by crystallization from $\mathrm{Et}_{2} \mathrm{O} /$ pentane $(1: 1)$ in $30 \%$ yield $(38 \mathrm{mg})$. Cis-8 (40 \%):IR(Nujol): v(IrH) $2160 \mathrm{~cm}^{-1}$. Elemental analysis calcd.for $\mathrm{C}_{63} \mathrm{H}_{57} \mathrm{BF}_{24} \mathrm{IrPSi}$ C, 49.39; $\mathrm{H}, 3.75$, found: $\mathrm{C}, 49.3 ; \mathrm{H}$, 3.6. ${ }^{1} \mathrm{H}$ NMR $\left(500 \mathrm{MHz}, \mathrm{CD}_{2} \mathrm{Cl}_{2}, 25^{\circ} \mathrm{C}\right) \delta: 7.41\left(\mathrm{~d}, 1 \mathrm{H}, \mathrm{H}_{\mathrm{a}}\right)$, $7.34\left(\mathrm{~m}, 2 \mathrm{H}, \mathrm{H}_{\mathrm{b}}, \mathrm{H}_{\mathrm{e}}\right), 7.26,7.01\left(\mathrm{dd}, 1 \mathrm{H}\right.$ each, ${ }^{4} J_{\mathrm{HP}}=4.2 \mathrm{~Hz}$, $\left.\mathrm{H}_{\mathrm{d}}, \mathrm{H}_{\mathrm{f}}\right), 7.05\left(\mathrm{dd}, 1 \mathrm{H},{ }^{4} J_{\mathrm{HP}}=4.1 \mathrm{~Hz}, \mathrm{H}_{\mathrm{c}}\right), 4.85\left(\mathrm{~d}, 1 \mathrm{H},{ }^{3} J_{\mathrm{HH}}=\right.$ $11.7 \mathrm{~Hz}, \mathrm{CH}_{\alpha}$ ), 2.62, 1.53 (s, $3 \mathrm{H}$ each, $\mathrm{Me}_{\beta}, \mathrm{Me}_{\gamma}$ ), 2.52 (d, $3 \mathrm{H}$, $\left.{ }^{2} J_{\mathrm{HP}}=10.5 \mathrm{~Hz}, \mathrm{PMe}\right), 2.38\left(\mathrm{~d}, 1 \mathrm{H},{ }^{3} J_{\mathrm{HH}}=11.7 \mathrm{~Hz}, \mathrm{CH}_{\beta}\right), 1.89$ 
$\left(\mathrm{s}, 3 \mathrm{H}, \mathrm{Me}_{\alpha}\right), 1.70\left(\mathrm{~d}, 15 \mathrm{H},{ }^{4} J_{\mathrm{HP}}=1.6 \mathrm{~Hz}, \mathrm{C}_{5} \mathrm{Me}_{5}\right), 0.13(\mathrm{~s}, 9$ $\left.\mathrm{H}, \mathrm{SiMe}_{3}\right),-15.85\left(\mathrm{~d}, 1 \mathrm{H},{ }^{2} J_{\mathrm{HP}}=30.7 \mathrm{~Hz}, \mathrm{IrH}\right) .{ }^{13} \mathrm{C} \operatorname{NMR}(125$ $\left.\mathrm{MHz}, \mathrm{CD}_{2} \mathrm{Cl}_{2}, 25{ }^{\circ} \mathrm{C}\right) \delta: 147.2\left(\mathrm{~d},{ }^{2} J_{\mathrm{CP}}=27 \mathrm{~Hz}, \mathrm{C}_{1}\right), 142.2$, $140.5\left(\mathrm{~d},{ }^{2} J_{\mathrm{CP}}=10,8 \mathrm{~Hz}, \mathrm{C}_{4}, \mathrm{C}_{6}\right), 141.6\left(\mathrm{C}_{3}\right), 132.3,131.6$ $\left(\mathrm{CH}_{\mathrm{b}}, \mathrm{CH}_{\mathrm{e}}\right), 131.3\left(\mathrm{~d},{ }^{3} J_{\mathrm{CP}}=10 \mathrm{~Hz}, \mathrm{CH}_{\mathrm{d} / \mathrm{f}}\right), 130.9\left(\mathrm{~m}, \mathrm{CH}_{\mathrm{c}}\right.$, $\left.\mathrm{CH}_{\mathrm{d} / \mathrm{f}}\right), 128.8\left(\mathrm{C}_{2}\right.$, overlapped with $\left.\mathrm{BAr}_{\mathrm{F}}\right), 127.3\left(\mathrm{~d},{ }^{3} J_{\mathrm{CP}}=17\right.$ $\left.\mathrm{Hz}, \mathrm{CH}_{\mathrm{a}}\right), 124.4\left(\mathrm{~d},{ }^{1} J_{\mathrm{CP}}=49 \mathrm{~Hz}, \mathrm{C}_{5}\right), 101.0\left(C_{5} \mathrm{Me}_{5}\right), 71.6(\mathrm{~d}$, $\left.{ }^{2} J_{\mathrm{CP}}=4 \mathrm{~Hz}, \mathrm{CH}_{\alpha}\right), 44.4\left(\mathrm{CH}_{\beta}\right), 28.4\left(\mathrm{~d},{ }^{1} J_{\mathrm{CP}}=48 \mathrm{~Hz}, \mathrm{PMe}\right)$, $25.8,22.5\left(\mathrm{~d},{ }^{3} J_{\mathrm{CP}}=5,8 \mathrm{~Hz}, \mathrm{Me}_{\beta}, \mathrm{Me}_{\gamma}\right), 19,8\left(\mathrm{~d},{ }^{3} J_{\mathrm{CP}}=4 \mathrm{~Hz}\right.$, $\left.\mathrm{Me}_{\alpha}\right), 8.6\left(\mathrm{C}_{5} \mathrm{Me}_{5}\right), 0.0\left(\mathrm{SiMe}_{3}\right){ }^{31} \mathrm{P}\left\{{ }^{1} \mathrm{H}\right\} \mathrm{NMR}(200 \mathrm{MHz}, \mathrm{CD}-$ $\left.{ }_{2} \mathrm{Cl}_{2}, 25^{\circ} \mathrm{C}\right) \delta$ : -7.6 . Trans -8 (53\%): It could not be isolated in pure form, but representative spectroscopic data include: ${ }^{1} \mathrm{H}$ $\operatorname{NMR}\left(500 \mathrm{MHz}, \mathrm{CD}_{2} \mathrm{Cl}_{2}, 25^{\circ} \mathrm{C}\right) 4.36\left(\mathrm{~d},{ }^{3} \mathrm{~J}_{\mathrm{HH}}=12.7 \mathrm{~Hz}, \mathrm{CH}_{\alpha}\right)$, $2.27\left(\mathrm{PMe}\right.$ and $\left.\mathrm{CH}_{\beta}\right), 1.94\left(\mathrm{C}_{5} \mathrm{Me}_{5}\right), 0.26\left(\mathrm{SiMe}_{3}\right)$ and $-16.84(\mathrm{~d}$, $\left.{ }^{2} J_{\mathrm{CP}}=30.7 \mathrm{~Hz}, \mathrm{Ir}-\mathrm{H}\right)$ ppm. ${ }^{31} \mathrm{P}\left\{{ }^{1} \mathrm{H}\right\} \mathrm{NMR}\left(200 \mathrm{MHz}, \mathrm{CD}_{2} \mathrm{Cl}_{2}\right.$, $\left.25^{\circ} \mathrm{C}\right) \delta: 0.9 \mathrm{ppm}$.

\section{Associated Content}

Supporting Information: kinetic studies on the isomerization of compound $\mathbf{5}$ and X-ray crystallographic studies.

\section{References}

1. (a) Arduengo, J. A.; Bertrand, G. Chem. Rev. 2009, 109, 32093884 (special issue dedicated to carbenes). (b) Crabtree, R. H. J. Organomet. Chem. 2005, 690, 5451-5457; (c) Díez-González, S., Nolan, S.P. Coord. Chem. Rev. 2007, 251, 874-883.

2. (a) Lavallo, V.; Canac, Y.; Prasang, C.; Donnadieu, B.; Bertrand, G. Angew. Chem. Int. Ed. 2005, 44, 5705-5709; (b) Jazzar, R.; Dewhurst, R. D.; Bourg, J. B.; Donnadieu, B.;Canac, Y.; Bertrand, G. Angew. Chem. Int. Ed. 2007, 46, 2899-2902; (c) Zeng, X.; Frey, D. G.; Kinjo, R.; Donnadieu, B.; Bertrand, G. J. Am. Chem. Soc. 2009, 131 ,8690-8696; (d) Chu, J., Munz, D., Jazzar, R., Melaimi, M., Bertrand, G. J. Am. Chem. Soc. 2016, 138, 7884-7887; (e) Roy, S.; Mondal, K. C.;Roesky, H. W. Acc. Chem. Res. 2016, 49, 357-369.

3. Selected examples: (a) Miki, S.; Ogno, T.; Iwasaki, H.; Yoshida, Z.-I. J. Phys. Org. Chem.1988, 1, 333-338; (b) Lu, Z.; Jones, W. M.; Winchester, W. R. Organometallics 1993, 12, 1344-1350; (c) Öfele, K.; Tosh, E.; Taubmann, C.; Herrmann, W. A. Chem. Rev. 2009, 109, 3408-3444.

4. (a) Carmona, E.; Paneque, M.; Poveda, M. L. Dalton Trans. 2003, 4022-4029; (b) Conejero, S.; Paneque, M.; Poveda, M. L.; Santos, L. L.; Carmona, E. Acc. Chem. Res. 2010, 43, 572-580; (c) Werner, H. Angew. Chem., Int. Ed. 2010, 49, 4714; (d) Whited, M. T.; Grubbs, R. H. Acc. Chem. Res. 2009, 42, 1607-1616; (e) Valpuesta, J. E. V.; Álvarez, E.; López-Serrano, J.; Maya, C.; Carmona, E. Chem. Eur. J. 2009, 18, 13149-13159.

5. (a) Hoover, J. F.; Stryker, J. M. J. Am. Chem. Soc. 1990, 112, 464465; (b) Casty, G. L.; Stryker, J. M. Organometallics 1997, 16, 3083-3085; (c) Holtcamp, M. W.; Henling, L. M.; Day, M. W.; Labinger, J. A.; Bercaw, J. E. Inorg. Chim. Acta 1998, 270, 467478; (d) Owen, J. S.; Labinger, J. A.; Bercaw, J. E. J. Am. Chem. Soc. 2006, 128, 2005-2016; (e) Lee, D.-H-; Chen, J.; Faller, J. W.; Crabtree, R. Chem. Commun. 2001, 213-214; (f) Clot, E.; Chen,
J.; Lee, D.-H.; Sung, S. Y.; Appelhans, L. N.; Faller, J. W.; Crabtree, R. H.; Eisenstein, O. J. Am. Chem. Soc. 2004, 126, 87958804.

6. (a) Herndon, J. W. Coord. Chem. Rev. 2011, 255, 3 (annual survey covering the year 2009; see references therein for previous years); (b) Caulton, K. G. J. Organomet. Chem. 2001, 56, 617-618.

7. (a) Dötz, K. H. Metal Carbenes in Organic Synthesis. Springer, 2004; (b) Dörwald, F. Z. Metal Carbenes in Organic Synthesis. Wiley-VCH: Weinheim, Germany, 2008; (c) Moss, R. A.; Doyle, M. P. Contemporary Carbene Chemistry. John Wiley \& Sons, 2014.

8. For early review articles see: (a) Aguero, A.; Osborn, J. A. New J. Chem. 1988, 12, 111-118; (b) Brothers, P. J.; Roper, W. Chem. Rev. 1988, 88, 1293-1326; (c) Gallop, M. A.; Roper, W. R. Adv. Organomet. Chem. 1986, 25, 121-198; (d) Herrmann, W. A. Adv. Organomet. Chem. 1982, 20, 159-263.

9. (a) Chauvin, Y. Angew. Chem. Int. Ed. 2006, 45, 3740-3747; (b) Schrock, R. R. Angew. Chem. Int. Ed. 2006, 45, 3748-3759; (c) Grubbs, R. H. Angew. Chem. Int. Ed. 2006, 45, 3760-3765.

10. For recent examples see: (a) Poverenov, E.; Milstein, D. Chem. Commun. 2007, 3189-3191; (b) Burford, R. J.; Piers, W. E.; Parvez, M. Organometallics 2012, 31, 2949-2952; (c) Doyle, L. E.; Piers, W. E.; Borau-Garcia, J.; Sgro, M. J.; Spasyuka, D. M. Chem. Sci. 2016, 7, 921-931; (d) Yuan, J.; Hughes, R. P.; Rheingold, A. L. Dalton Trans. 2015, 44, 19518-19527.

11. (b) Fryzuk, M. D.; Macneil, P. A.; Rettig, S. J. J. Am. Chem. Soc. 1985, 107, 6708-6710. (c) Fryzuk, M. D.; Gao, X.; Joshi, K.; MacNeil, P. A.; Massey, R. L. J. Am. Chem. Soc. 1993, 115, 1058110590; (d) Klein, D. P.; Bergman, R. G. J. Am. Chem. Soc. 1989, 111, 3079-3080; (e) Campos, J.; Peloso, R.; Brookhart, M.; Carmona, E. Organometallics2013, 32, 3423-3426.

12. (a) Lara, P.; Paneque, M.; Poveda, M. L.; Santos, L. L.; Valpuesta, J. E. V.; Carmona, E.; Moncho, S.; Ujaque, G.; Lledós, A.; Álvarez, E.; Mereiter, K. Chem. Eur. J. 2009, 15, 9034-9045; (b) Lara, P.; Paneque, M.; Poveda, M. L.; Santos, L. L.; Valpuesta, J. E. V.; Salazar, V.; Carmona, E.; Moncho, S.; Ujaque, G.; Lledós, A.; Maya, C.; Mereiter, K. Chem. Eur. J. 2009, 15, 9046-9057; (c) Paneque, M.; Poveda, M. L.; Santos, L. L.; Carmona, E.; Lledós, A.; Ujaque, G.; Mereiter, K. Angew. Chem. Int. Ed. 2004, 43, 3708-3711.

13. (a) Alías, F. M.; Poveda, M. L.; Sellin, M.; Carmona, E. J. Am. Chem. Soc. 1998, 120, 5816-5817; (b) Besora, M.; Vyboishchikov, S. F.; Lledós, A.; Maseras, F.; Carmona, E.; Poveda, M. L. Organometallics 2010, 29, 2040-2045; (c) Alías, F. M.; Poveda, M. L.; Sellin, M.; Carmona, E.; Gutiérrez, E.; Monge, A. Organometallics 1998, 17, 4124-4126.

14. (a) Paneque, M.; Posadas, C. M.; Poveda, M. L.; Rendon, N.; Mereiter, K. Organometallics 2007, 26, 1900-1906; (b) Luecke, H. F.; Bergman, R. G. J. Am. Chem. Soc. 1998, 120, 11008-11009; (d) Thorn, D. L.; Tulip, T. H. J. Am. Chem. Soc. 1981, 103, 59845986; (e) Thorn, D. L. Organometallics 1982, 1, 879-885; (f) Thorn, D. L.; Tulip, T. H. Organometallics 1982, 1, 1580-1586; (g) Bell, T. W.; Haddleton, D. M.; McCamley, A.; Partridge, M. G.; Perutz, R. N.; Willner, H. J. Am. Chem. Soc. 1990, 112, 92129226; (h) France, M. B.; Feldman, J.; Grubbs, R. H. J. Chem. Soc., Chem. Commun. 1994, 1307-1308; (i) Bleeke, J. R.; Behm, R. J. Am. Chem. Soc. 1997, 119, 8503-8511.

15. Choi, J.; Wang, D. Y.; Kundu, S.; Choliy, Y.; Emge, T. J.; Krogh-Jespersen, K.; Goldman, A. S. Science 2011, 332, 1545-1548.

16. Polukeev, A. V.; Marcos, R.; Ahlquistb, M. S. G.; Wendt, O. F. Chem. Sci. 2015, 6, 2060. 
17. (a) Arndtsen, B. A.; Bergman, R. G. Science 1995, 270, 1970; (b) Burger, P.; Bergman, R. G. J. Am. Chem. Soc. 1993, 115, 10462.

18. (a) Campos, J.; Esqueda, A. C.; Carmona, E. Chem. Eur. J. 2010, 16, 419-422; (b) Campos, J.; Álvarez, E.; Carmona, E. New J. Chem. 2011, 35, 2122-2129; (c) Rubio, M.; Campos, J.; Carmona, E.Org. Lett. 2011, 13, 5236 -5239;(d) Campos, J.; Rubio, M.; Esqueda, A. C.; Carmona, E. J. Label. Compd. Radiopharm. 2012, $55,29-38$.

19. Campos, J.; Carmona, E. Organometallics 2015, 34, 2212-2221.

20. (a) Campos, J.; Esqueda, A. C.; López-Serrano, J.; Sánchez, L.; Cossio, F. P.; de Cozar, A.; Álvarez, E.; Maya, C.; Carmona, E. J. Am. Chem. Soc. 2010, 132, 16765-16767; (b) Campos, J.; López-Serrano, J.; Álvarez, E.; Carmona, E. J. Am. Chem. Soc. 2012, 134, 7165-7175; (c) Campos, J.; Espada, M. F.; López-Serrano, J.; Carmona, E. Inorg. Chem. 2013, 52, 6694-6704.

21. Espada, M. F.; López-Serrano, J.; Poveda, M. L.; Carmona, E. Angew. Chem. Int. Ed. 2015, 54, 8751-8755.

22. Crabtree R. H. The Organometallic Chemistry of the Transition Metals. Wiley, 2014.

23. Hartwig, J. F. Organotransition Metal Chemistry: From Bonding to Catalysis. University Science Books. 2010.

24. (a) Hayes, J. C.; Cooper, N. J. J. Am. Chem. Soc. 1982, 104, 5570557; (b) Guerchais, V.; Lapinte, C. J. Chem. Soc. Chem. Commun. 1986, 663-664.

25. (a) Campos, J.; Peloso, R.; Carmona, E. Angew. Chem. Int. Ed. 2012, 51, 8255 - 8258; (b) Campos, J.; Ortega-Moreno, L.; Conejero, S.; Peloso, R.; López-Serrano, J.; Maya, C.; Carmona, E., Chem. Eur. J. 2015, 21, 8883-8896.

26. Liu, L.; Zhang, J. Chem. Soc. Rev. 2016, 45, 506-516.

27. See for example: Cheng, T.-Y.; Brunschwig, B. S.; Bullock, R. M. J. Am. Chem. Soc. 1998, 120, 13121-13137.

28. Sattler, A.; Parkin, G. Chem. Commun. 2011, 47, 12828-12830.

29. (a) Hinderling, C.; Feichtinger, D.; Plattner, D.; Chen, P. J. Am. Chem. Soc. 1997, 119, 10793-10804; (b) Shinomoto, R. S.; Desrosiers, P. J.; Harper, T. G. P.; Flood, T. C. J. Am. Chem. Soc. 1990 , 112, 704-713; (c) Casalnuovo, A. L.; Calabrese, J. C.; Milstein, D.
J. Am. Chem. Soc. 1988, 110, 6738-6744; (d) Wenzel, T. T.; Bergman, R. G. J. Am. Chem. Soc. 1986, 108, 4856-4867.

30. See for instance: (a) Klahn, A. H.; Oelckers, B.; Godoy, F.; Garland, M. T.; Vega, A.; Perutz, R. N.; Higgitt, C. L. J. Chem. Soc., Dalton Trans. 1998, 3079-3086; (b) Fairchild, R. M.; Holman, K. T. Organometallics 2008, 27, 1823; (c) Fan, L.; Turner, M. L.; Hursthouse, M. B.; Malik, K. M. A.; Gusev, O. V.; Maitlis, P. M. J. Am. Chem. Soc. 1994, 116, 385; (d) Bandy, J. A.; Mtetwa, V. S. B.; Prout, K.; Green, J. C.; Davies, C. E.; Green, M. L. H.; Hazel, N. J.; Izquierdo, A.; Martin-Polo, J. J. J. Chem. Soc., Dalton Trans. 1985, 2037-2049.

31. (a) Alías, F. M.; Daff, P. J.; Paneque, M.; Poveda, M. L.; Carmona, E.; Pérez, P. J.; Salazar, V.; Alvarado, Y.; Atencio, R.; Sánchez-Delgado, R. Chem. Eur. J. 2002, 8, 5132-5146; (b) Paneque, M.; Poveda, M. L.; Santos, L. L.; Carmona, E.; Lledós, A.; Ujaque, G.; Mereiter, K. Angew. Chem. Int. Ed. 2004, 43, 3708-3711; (c) Lara, P.; Paneque, M.; Poveda, M. L.; Santos, L. L.; Valpuesta, J. E. V.; Carmona, E.; Moncho, S.; Ujaque, G.; Lledós, A.; Álvarez, E.; Mereiter, K. Chem. Eur. J. 2009, 15, 9034-9045; (d) Lara, P.; Paneque, M.; Poveda, M. L.; Santos, L. L.; Valpuesta, J. E. V.; Salazar, V.; Carmona, E.; Moncho, S.; Ujaque, G.; Lledós, A.; Maya, C.; Mereiter, K. Chem. Eur. J. 2009, 15, 9046-9057.

32. Jellema, E.; Jongerius, A. L.; Reek, J. N. H.; de Bruin, B. Chem. Soc. Rev. 2010, 39, 1706.

33. See for example: (a) Caballero, A.; Despagnet-Ayoub, E.; Díaz-Requejo, M. M.; Díaz-Rodríguez, A.; González-Núñez, M. E.; Mello, R.; Muñoz, B. K.; Ojo, W.-S.; Asensio, G.; Etienne, M.; Pérez, P. J. Science 2011, 332, 835-838; (b) Zheng, J.; Lin, J.-H.; Yu, L.-Y.; Wei, Y.; Zheng, X.; Xiao, J.-C. Org. Lett. 2015, 17, 6150-6153; (c) Holzwarth, M. S.; Alt, I; Plietker, B. Angew. Chem. Int. Ed. 2012, 51, 5351-5354; (d) Muller, P. Acc. Chem. Res. 2004, 37, 243-251.

34. (a) Braga, A. A. C.; Caballero, A.; Urbano, J.; Díaz-Requejo, M. M.; Pérez, P. J.; Maseras, F. ChemCatChem 2011, 3, 1646. (b) Hansen, J. H.; Parr, B. T.; Pelphrey, P.; Jin, Q.; Autschbach, J.; Davies, H. M. L. Angew. Chem. Int. Ed. 2011, 50, 2544. 